\title{
Climate of migration? How climate triggered migration from southwest Germany to North America during the 19th century
}

\author{
Rüdiger Glaser, Iso Himmelsbach, and Annette Bösmeier \\ Physical Geography, Albert-Ludwigs-Universität Freiburg, Freiburg, Germany \\ Correspondence to: Rüdiger Glaser (ruediger.glaser@geographie.uni-freiburg.de)
}

Received: 18 May 2017 - Discussion started: 13 June 2017

Accepted: 13 October 2017 - Published: 21 November 2017

\begin{abstract}
This paper contributes to the ongoing debate on the extent to which climate and climatic change can have a negative impact on societies by triggering migration, or even contribute to conflict. It summarizes results from the transdisciplinary project "Climate of migration" (funded 2010-2014), whose innovative title was created by Franz Mauelshagen and Uwe Lübken. The overall goal of this project was to analyze the relation between climatic and socioeconomic parameters and major migration waves from southwest Germany to North America during the 19th century. The article assesses the extent to which climatic conditions triggered these migration waves. The century investigated was in general characterized by the Little Ice Age with three distinct cooling periods, causing major glacier advances in the alpine regions and numerous climatic extremes such as major floods, droughts and severe winter. Societal changes were tremendous, marked by the warfare during the Napoleonic era (until 1815), the abolition of serfdom (1817), the bourgeois revolution (1847/48), economic freedom (1862), the beginning of industrialization accompanied by large-scale rural-urban migration resulting in urban poverty, and finally by the foundation of the German Empire in 1871 .

The presented study is based on quantitative data and a qualitative, information-based discourse analysis. It considers climatic conditions as well as socioeconomic and political issues, leading to the hypothesis of a chain of effects ranging from unfavorable climatic conditions to a decrease in crop yields to rising cereal prices and finally to emigration. These circumstances were investigated extensively for the peak emigration years identified with each migration wave. Furthermore, the long-term relations between emigration and the prevailing climatic conditions, crop yields and cereal prices
\end{abstract}

were statistically evaluated with a sequence of linear models which were significant with explanatory power between 22 and $38 \%$.

\section{Introduction}

Climate, climate variability and climate change can be seen as embedded in socioecological system approaches. They are amongst the main environmental factors influencing human societies in manifold interactive ways, even triggering migration or conflicts (McLeman, 2011; IPCC, 2014). This can be assumed in the modern context as well as for historical periods (Parry, 1981; Pfister and Brázdil, 2006; Büntgen et al., 2011; Wetter et al., 2014; Camenisch, 2015; Camenisch et al., 2016; Pribyl, 2017). Climate change is associated with a significant change in temperature and precipitation means and seasonality, as well as an increase in frequency and/or intensities of climatic extremes like floods, storms, droughts and extreme coldness. These general changes as well as single outstanding extremes are regarded as stressors to societies, and are, therefore, often incorporated into current risk analysis approaches. In many concepts risk is understood as a function of hazard, vulnerability (including exposure and sensitivity) and resilience (Turner et al., 2003; Wisner et al., 2004; Birkmann, 2013). Within such risk concepts, migration often is a key issue or indicator, and is regarded as an ultimate adaptation measure (Schenk, 2009; Herrmann, 2011; Engler et al., 2013).

Within the economically motivated migration theory, migration waves are often described as an interaction of socalled "push" and "pull" factors. This theoretical framework was initially conceptualized by Lee (1966), then developed further (Hammar et al., 1997) and supplemented by concepts 
such as "liquid migration" (e.g., Engbersen et al., 2010). The term "push factor" in Lee's concept subsumes all disadvantages and discriminations which a person feels and/or experiences in his or her home land. This comprises amongst others political and/or religious discrimination or an economic situation which is perceived as unfavorable. This could be due to insufficient opportunities to earn money, permanent food price increases or an agricultural rent system considered as unjust. "Pull factors" on the other hand describe all the different positive expectations potential emigrants have of their target countries. These include ideas of political and economic freedom as well as prospects of better economic opportunities (Oltmer, 2010), e.g., easier property acquisition, commercial freedom or the availability of fertile farmland as a free commodity. The push-and-pull concept was complemented by the theory of "network"or "chain" migration. It describes how the so-called "pioneer migrants" motivate their relatives and friends to migrate, supporting them with information and financial help.

Recently, an increasing number of discussions have emerged on the influence of climatic conditions and natural hazards on migration. Climate and climatic variability, often considered as an independent group within the push factors, have been discussed and presented as crucial environmental factors influencing human migration in diverse scientific studies (e.g., Hugo, 1996; Lutz et al., 2002; Hunter, 2005; McLeman, 2013). The effect of climatic conditions on population dynamics and societal success and/or failure at different scales during ancient and prehistoric times, including settlement patterns and migration processes, is described at a mesoscale level by Lamb (1982), Diamond (2005), Linden (2006) and Fagan (2008). Decision processes and underlying causes leading to migration are governed by various other factors besides climate-related circumstances, like social, political, economic and governmental factors (McLeman and Smith, 2006). Nevertheless, current discussions consider climate and climatic change to play an important role within migration processes (McLeman, 2011; IPCC, 2014).

In this context, an investigation of interconnections between climate and emigration from southwest Germany during the 19th century seems to be a valuable case study. In this study we evaluate and quantify to what degree climate influenced migration from this region in the course of the 19th century. Many scientific studies give an important role leading to emigration from southwest Germany during the 18th and the beginning of the 19th century to religious disputes (Tuchtenhagen, 1999) and direct recruitment of settlers (Scheuerbrandt, 1985). Regarding the period of the 19th century, research has focused on economic reasons and emphasized, in particular, a lack of income and latent poverty as main factors (Megerle, 1982) as well as an overall lack of life chances (Bayer, 1966; Marschalck, 1973; von Hippel, 1984; Meier-Braun and Weber, 2009; Twyrdy, 2010; Boyd, 2013).
Abel (1972) highlighted the importance of the recurring agricultural crises during the 19th century for emigration.

The research period extends from the end of the Little Ice Age (LIA) with lower mean temperatures - nearly $1{ }^{\circ} \mathrm{C}$ in comparison to the 1961-1990 climate normals - and the transition to the period of anthropogenic climate change. This general trend includes a high year-to-year variability with single extreme years and outstanding seasonal extremes as well as hazards like floods, frost periods and droughts. These climatic developments as well as the year-to-year variability can be seen as "stressors" to societies. According to general climatic definitions, "normal" is defined within a range of minus 1 to plus 1 standard deviation from the mean. Events exceeding this range or thresholds are defined as remarkable or extreme, expressed in terms like "hot", "dry", "cold" or "wet".

Population development, harvest failure and subsequent price increases also seem to have played an important role, whereby climatic conditions predominantly affected the harvests and the quality of the products and thus food prices.

Our approach focuses on the reaction chain of climatic conditions influencing harvest and subsequently pricing and migration, which was modeled statistically to quantify a climatically induced effect on migration numbers. Additionally, socioeconomic, political and societal factors of the main migration waves were discussed to explore the complex, multifold process of migration.

\section{Study area}

The study area - the present German state of BadenWürttemberg - is situated in southwest Germany. From Napoleonic times onwards, this area comprised the sovereign states of the Grand Duchy of Baden, the Kingdom of Württemberg and the principality of Hohenzollern-Sigmaringen, which was part of the Kingdom of Prussia (see Fig. 1). In the western part, this area included the Upper Rhine Plain, which in the eastern part is bordered by the mountain ranges of Odenwald and Black Forest. The Swabian Alb is located further east. Towards the south, the High Rhine (Hochrhein) and Lake Constance form the borders to Switzerland and Austria.

Climatically the study area belongs to the so-called maritime-influenced mid-latitudes with a temperate climate, expressed by a yearly temperature mean of $+9^{\circ} \mathrm{C}$ and $1000 \mathrm{~mm}$ annual precipitation with a slight maximum in summertime, but year-round precipitation $(\mathrm{Cfb}$ after Köppen-Geiger - indicating a warm temperate climate, fully humid, with warm summers). The year-to-year variability is relatively high and various extremes occur, e.g., flood events, prolonged cold periods and storms in winter as well as heat waves and droughts. Regional differences exist between the low-lying and somewhat warmer Upper Rhine Plain, indicated by deciduous forest dominated by oak species, and the cooler mountainous areas of the Black Forest and the 


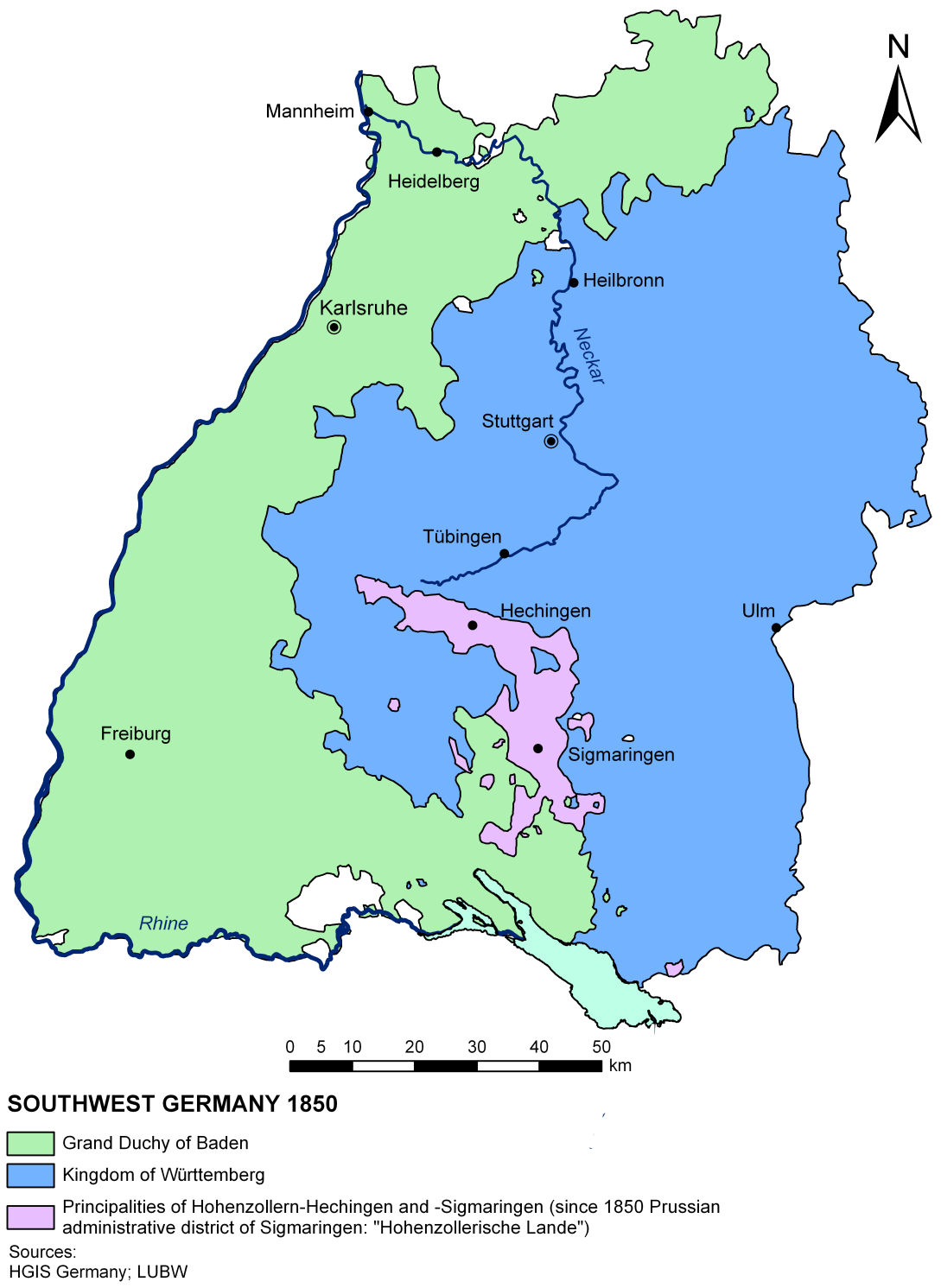

Figure 1. Study area including the historical boundaries.

Swabian Alb reaching up to nearly $1500 \mathrm{~m}$, mainly covered with mixed forest, with a high proportion of beech and spruce. Due to the topographic situation, the annual precipitation varies between 500 and $2000 \mathrm{~mm}$. Soil conditions also change from rich Luvisols above loess to poor podzolic Cambisols and Podzols above igneous rocks. These regional climatic and soil variations explain the differentiated ecological conditions, which had a significant influence on harvest results and their regional variations.

The present main land use types comprise $38.3 \%$ forest cover; $13.3 \%$ settlement and built-up areas, infrastructure, and bare grounds; $45.4 \%$ agricultural areas including meadows; $1.1 \%$ water bodies; $0.9 \%$ recreation areas; and $0.7 \%$ diverse areas (Statistisches Landesamt, 2015). In 1868 the main land use types in Württemberg comprised $31 \%$ forest cover and $57 \%$ agricultural areas including meadows and in Baden $33 \%$ forest cover and also 57\% agricultural areas including meadows (von Viebahn, 1868). Local and regional studies indicate substantially lower settlement, built-up areas and infrastructure (3-4\%), wetland areas and wet meadows $(2 \%)$, and a slightly lower proportion of water bodies $(0.8-$ $0.9 \%)$.

\section{Working hypothesis, data sources and methodological concept}

The aim of this study is the analysis and quantification of the effects of climatic conditions on migration. The underlying hypothesis is that emigration in the 19th century was a consequence of climate and other environmental, as well 


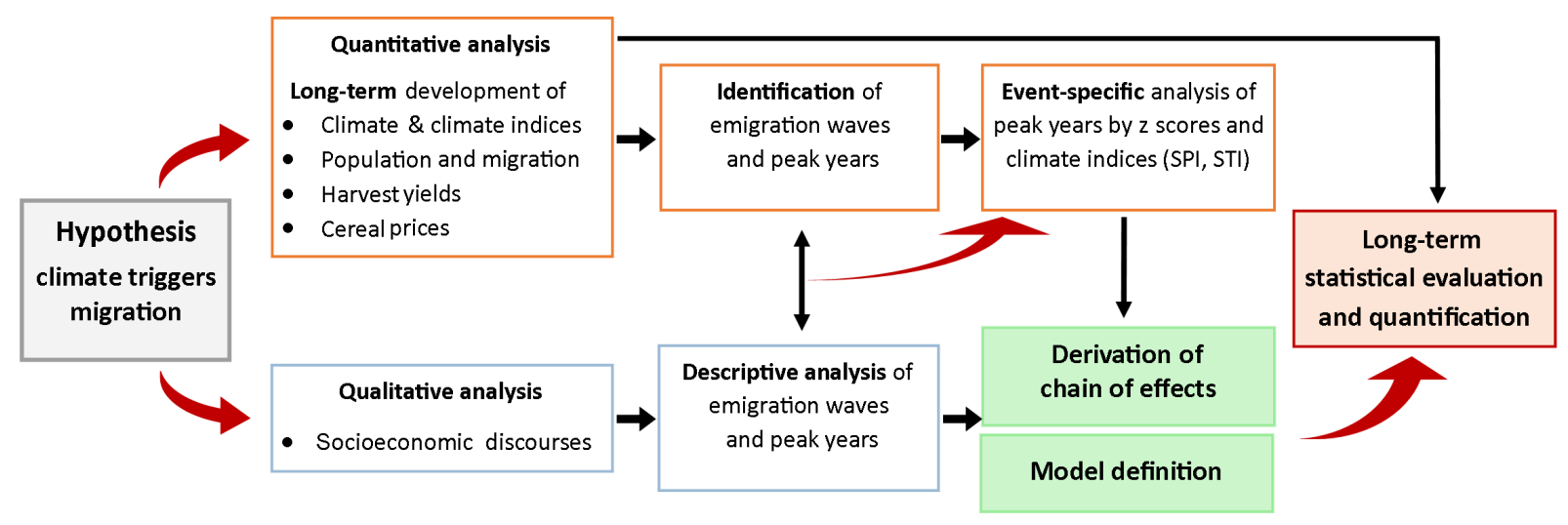

Figure 2. Framework for the evaluation of climatic, socioeconomic and agricultural influences on migration.

as economic and sociopolitical factors. The main drivers were considered to be population growth itself as well as changes in harvests and subsequent price developments; additional presumed push factors were earning opportunities, latent poverty and religious and political discrimination, as well as a general lack of life chances. Some of these factors, e.g., harvests, quality and pricing, are influenced by climate to some degree. This hypotheses is supported by the results given by Bauernfeind and Woitek (1999), who analyzed the relation between weather conditions and harvests in the southern and western parts of Germany during the 16th century - but for the 19th century and in connection with migration it has hardly been examined.

Firstly, relevant numerical data on migration development and the assumed influencing factors were collected and compiled.

Secondly, to evaluate in more depth the emergence of specific waves of emigration, an additional analysis of qualitative, descriptive data with respect to social, economic and sociopolitical factors was carried out. Finally, statistical models were constructed to test and quantify the assumed correlations and linkages between the identified drivers of emigration on a long-term basis. In Fig. 2 the conceptual framework is outlined.

\subsection{Population development and migration}

A compilation of population data in the German southwest was used. It was collected by the project histat (Historical statistics) using consistent and documented criteria (https:// histat.gesis.org/histat/).

The information on emigration is based on the official migration statistics for the Kingdom of Württemberg taken from von Hippel (1984), Güll (2013) and the "Württembergischen Jahrbücher" (WJB), which began publication in 1818. For the Grand Duchy of Baden official migration statistics are available from 1850 onwards (Statistische Mitteilungen über das Großherzogtum Baden, 1881), while for the period between 1840 and 1849 there are only a total of 23966 emigrants (Großherzogtum Baden, 1857). The emigration data were used to identify periods with an above-average number of emigrants, which we referred to as "waves". Focusing on the so-called "peak years", the resulting waves of migration were characterized by assessing appropriate indicators as described above.

\subsection{Harvests and pricing}

For the assessment of long-term trends of harvests, annual data of cereal crop yields (rye, oat, barley, spelt and wheat) and potatoes, published yearly in the WJB from 1846 to 1886 , were used. The reference value for the crop yields was the so-called Mittelernte (mean harvest). This term is not equivalent to "average yield" but rather took into account factors such as cultivation area, harvest per area and crop quality (comparable to the specific weight of every crop), which was calculated yearly. The Mittelernte was given a mean value of 100 , with better harvests obtaining a higher value and poorer harvest a lower value.

With regard to the Kingdom of Württemberg the mean annual prices for the cereals rye, oat, barley, spelt, wheat and hulled spelt (Kernen), which are available from 1766 onwards, were also taken from the WJB $(1896,2)$. For the Grand Duchy of Baden data are only available for the periods between 1833 and 1850 and from 1868 to 1886 . On account of this data gap for Baden which cannot be repaired (Borcherdt et al., 1989), the following evaluation only includes the time series for Württemberg. For each time of crisis, the relevant price data were collected from different newspapers, archival sources and collections.

To obtain an overview of whether and how the development of grain prices correlated with the waves of emigration, the development of emigration from Württemberg was compared qualitatively with the annual average grain prices (Fig. 5). However, pricing does not exclusively reflect harvests as it was also subject to speculative share trading. Therefore it was also necessary to refer to other contempo- 
rary sources (e.g., newspapers, local and city chronicles) to assess the relationship between crop yields and pricing.

\subsection{Climate information}

The climate information available as measurement data in monthly resolution was compiled from the KNMI Climate Explorer (Royal Netherlands Meteorological Institute, Dutch national weather service, http://www.knmi.nl/home), the CRU (Climatic Research Unit (England, University of East Anglia), http://www.cru.uea.ac.uk/) and the German Meteorological Service (DWD, http://www.dwd.de). Historical data were retrieved from the collaborative research environment for climate and environmental history (http://www. tambora.org/).

While the establishment of the official weather recording started late this century (around the 1880s), there are quite a number of homogeneous time series available (with some gaps) for the cities of Karlsruhe (Baden), Stuttgart (Württemberg), and partly also for Heilbronn (Württemberg) (KNMI, CRU, DWD). In addition, there are a broad variety of further sources, like chronicles of grape harvests, early local chronicles, newspapers or administrative acts. On the basis of monthly precipitation sums and monthly temperature averages, the standardized precipitation index (SPI) and the standardized temperature index (STI) were derived for further analyses as explained below.

\subsection{Interaction between climate and phenology}

It is clear that climate influences harvest in manifold ways. The interaction between climate and phenology in the German southwest starts for winter grain at the end of September of the preceding year with the seeding and ends with the harvest in July. The cultivation of summer grain starts with seeding at the end of February until the end of March and ends with the harvest also in July.

The important phenological stages between seeding, ear emergence and blooming are affected by weather conditions. In general, negative impacts on harvests are, for example, caused by extremely cold winters (often represented by frozen rivers as an additional indicator or long-lasting snow cover) that led to plant death. This can already occur below $-10{ }^{\circ} \mathrm{C}$, depending on soil and snow cover conditions. Yet this adverse constellation could be partly compensated for by a secondary seeding of summer grain in springtime. However, winter cereals also have "cold requirements": they need a few weeks of persistent cold temperatures during winter for being capable of flowering - a process which is called "vernalization" (Chouard, 1960).

Damages to yields can, furthermore, be caused by cold and extreme wet or dry spring conditions, which are often indicated by flooding. Also, hot and dry or cold and wet summers had a negative influence on the harvests. These temperature and precipitation conditions were taken into account for this study at a seasonal scale, while single short-term events like frost periods or thunderstorms were not considered.

\subsection{Analysis of specific events}

Temperature, precipitation, crop yields and cereal prices were considered as the main climatically influenced drivers of the effect variable emigration; these variables were used for an event-specific quantitative analysis.

In order to obtain an integrated view of those indicators assumed relevant for migration, standardized values for the times of the migration peaks were evaluated (see Fig. 7). Since the database for the research area of Baden was too scarce, the analyses were only applied to the Württemberg region. The data set consists of the monthly mean temperatures and precipitation sums of the meteorological stations of Stuttgart (DWD, KNMI) and Stuttgart-Echterdingen (CRU; Harris et al., 2014). The sources for harvests, prices and emigration data are the ones mentioned above.

The data were standardized to allow for direct comparisons. The underlying time intervals for standardization thereby depend on data availability, unless indicated otherwise. The annual data of crop yields and cereal prices were standardized by $z$ transformation following Eq. (1) (Bortz and Schuster, 2010):

$z=\frac{x-\bar{x}}{s}$.

A standardized value $z$, the $z$ score, is defined by the deviation of the initial value $x$ from the mean $\bar{x}$ divided by the standard deviation $s$.

To attain a standardized, temporal aggregation of the initial monthly data of temperature and precipitation on seasonal scale, the 3-monthly and 6-monthly SPI and STI were used. The SPI can be determined on the basis of one or several months and represents the deviation from the mean for a specified period divided by the standard deviation (McKee et al., 1993); the STI can be computed analogically. These indices allow classifying temperature and precipitation conditions of one or several months within a time series of many years. For instance, the 3-monthly SPI or STI of May and August indicate the degree of precipitation or temperature during the spring (March-May) and summer (June-August) season, while the 6-monthly SPI and STI of August represent indicators for the spring and summer half-year (MarchAugust). The reference period for the calculation of the SPI was, due to data availability, 1825-1886 (station Stuttgart), for earlier years the SPI was calculated on basis of data from Stuttgart-Echterdingen (15 km south of the station Stuttgart) with the reference period of 1807-1886. The STI was calculated for Stuttgart for the reference period of 1804-1886. The calculations were made using the software environment $\mathrm{R}$, version 3.1.3 (R Core Team, 2015), and particularly the $\mathrm{R}$ packages "Hmisc" (Harrell Jr. et al., 2016), "SPEI" (Vicente- 


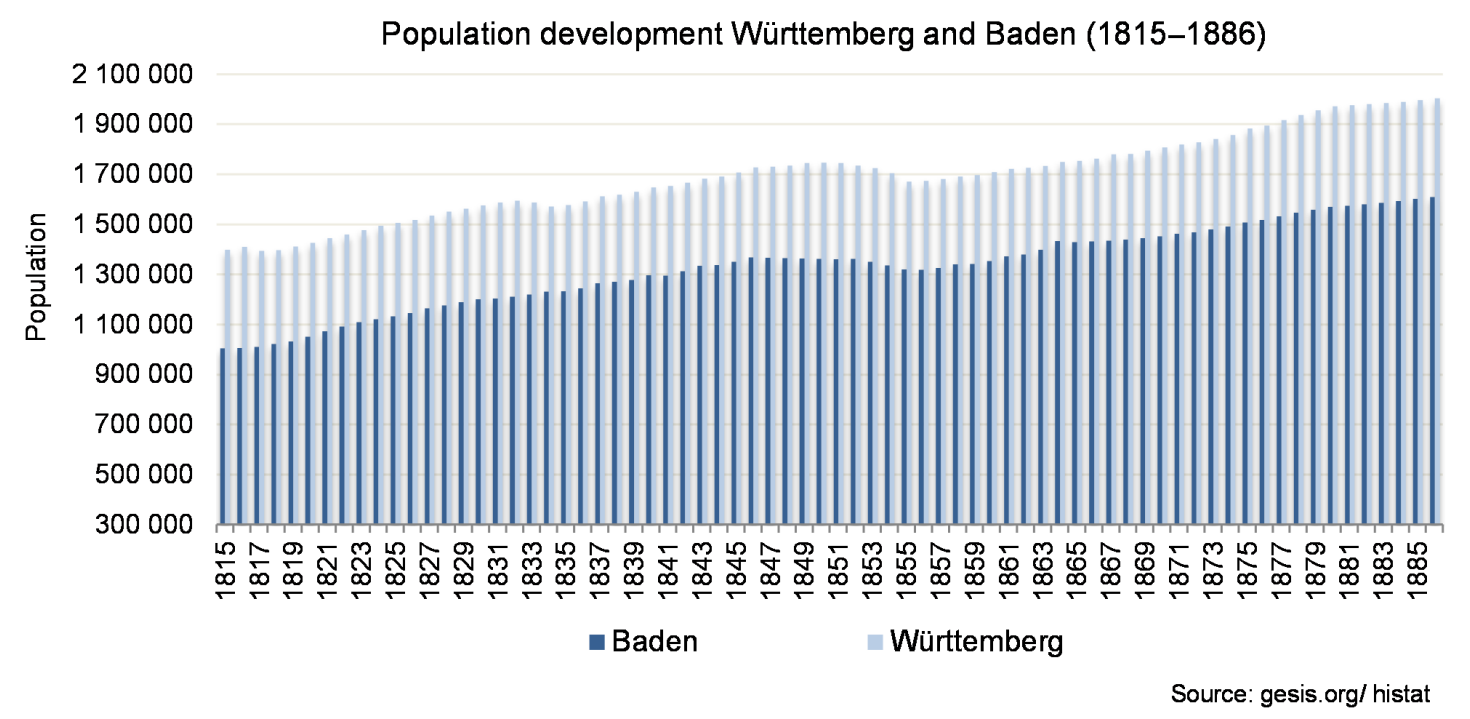

Figure 3. Population development in Baden and Württemberg (1815-1886).

Serrano et al., 2010; Beguería and Vicente-Serrano, 2013) and "STI" (Fasel, 2015).

\subsection{Analysis of long-term trends}

For a quantitative estimation of the climatic influence on the observed emigration, an assessment of the long-term relationship between the related variables was carried out. The method used was a statistical analysis of the joint indicators temperature, precipitation, cereal and potato yields, and cereal prices, as well as their influence on the target value, emigration. This was explored by linear regression modeling of the particular connections within the assumed chain of effects. The analyses were performed on the data introduced for the maximum time period, based on the availability of the individual data sets. So, for example, the availability of crop yield data limited the time interval for observations including this variable to the period 1846-1886. Taking into account that every food plant needs different climatic conditions during the year for optimal growth, we separately modeled the climatic dependence of cereal crops and potatoes.

The assumption of normality was checked and verified by the Lilliefors test (Gross and Ligges, 2015), with normal distribution only rejected for total migration numbers: according to the likelihood and the data type (discrete), a negative binomial distribution was chosen for this variable. Regression analyses on the relationships between the different variables were performed using $\mathrm{R}$ ( $\mathrm{R}$ Core Team, 2015):

- Cereal crop yields $\sim$ STI + SPI: a linear model of mean annual cereal crop yields (mean of wheat, barley, oat, spelt and rye) as a function of the 6-monthly STI and the 6-monthly SPI (considered as descriptors for weather conditions during the course of the previous 6 months) was constructed for the time interval of 1846-1885.
- Potato crop yields $\sim$ STI + SPI: a further linear model of potato crop yields as a function of the STI and the SPI was constructed for the time interval of 1846-1885.

- Cereal prices $\sim$ cereal crop yields: the effect of mean cereal crop yields on mean cereal prices of the subsequent year was modeled for the mean of the crops of barley, oat, spelt and rye for the period of 1846-1886.

- Migration $\sim$ cereal prices: finally, a generalized linear model was used to assess the effect of cereal prices (mean of the prices of barley, oat, spelt, rye and hulled spelt) on migration numbers within the time interval 1816-1886.

\section{The long-term development of population, migration, harvests, pricing and climate}

In the following, we present the long term development of population, harvests, pricing and climate as well as migration from the German southwest during the 19th century.

\subsection{Overall population development and migration in southwest Germany during the 19th century}

The population development shows a general population growth in Baden and Württemberg between 1815 and 1886 (Fig. 3); slight declines are only recorded for the periods 1817/18, 1833/34 and 1851-1855 (Württemberg) and $1817,1833 / 34$ and 1851-1855 (Baden). In the emigration debate during the 19th century the keyword "overpopulation" played an important role. The Napoleonic era (Napoleon I, 1769-1821) contributed to comparatively large territories and population growth in Baden and Württemberg: in 1806, Württemberg became a kingdom and Baden a grand duchy. 


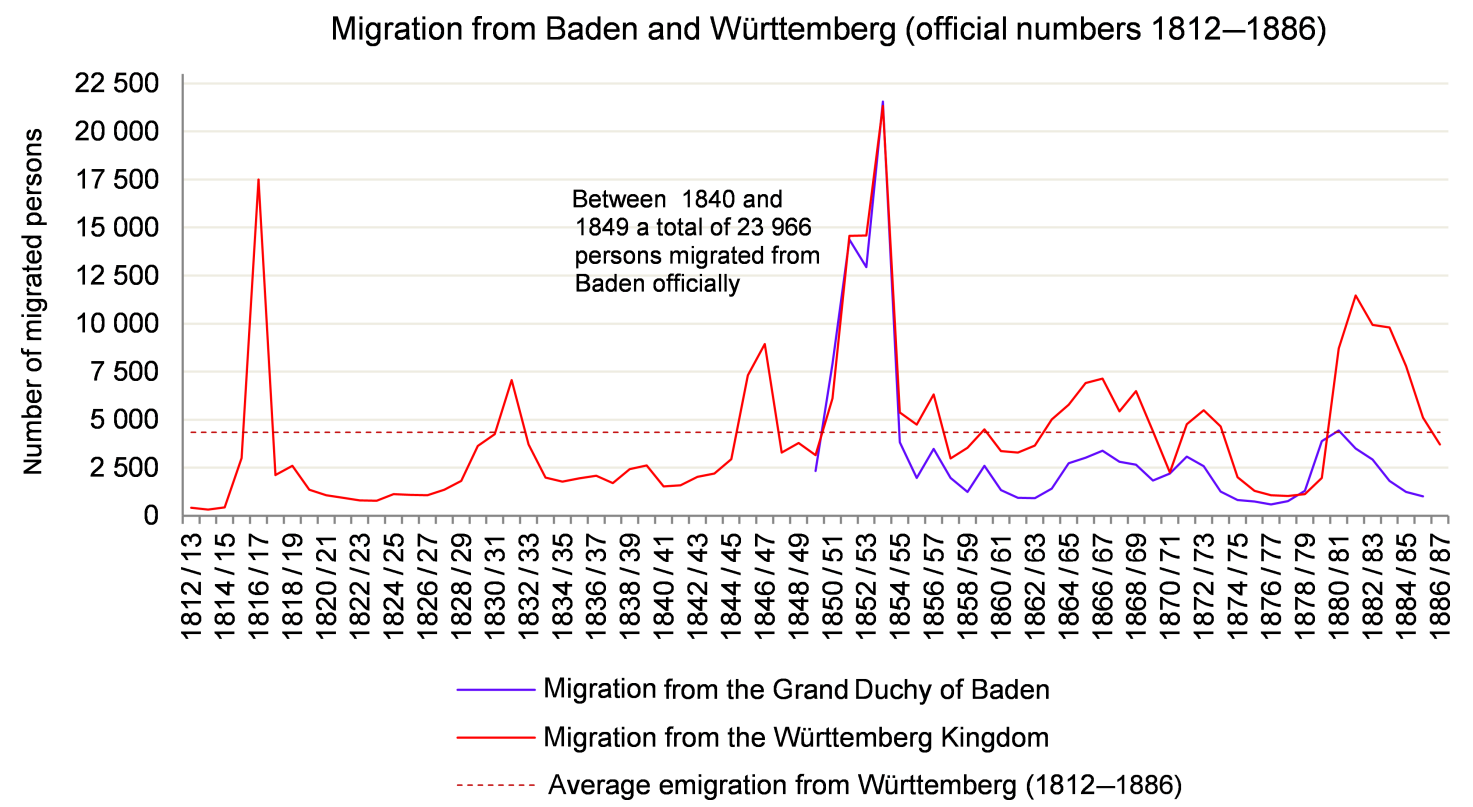

Figure 4. Official numbers of emigrants from Württemberg and Baden (1812-1886).

Both doubled the areas of their dominions and thus also had twice as many inhabitants to feed. In 1815 , this process was basically completed. Both countries gained areas with completely different legal traditions and religious affiliations, because of which the administrations took a relatively long time to adapt to the new situation.

Figure 4 shows the annual development of the official migration from Baden and Württemberg during the period from 1812 to 1886 . The dashed line represents the average migration from Württemberg during this period (4339 persons). The underlying data were collected every year at the end of September; therefore they refer to the period from October of the previous year to September of the year in question.

Six distinct emigration waves were detected on which our research is focused. Three of them clearly stand out, namely those of 1815-1817, 1850-1855 and 1881-1883, which experienced their peak years in 1816/17, 1853/54 and $1881 / 82$, respectively. Three secondary waves were identified for the years 1830-1832, 1845-1847 and 1863-1869, with their respective peaks in 1831/32, 1846/47 and 1866/67. As the sources provide reliable data for Baden only from the 1840s onward, the long-term analysis was carried out only for Württemberg. It can be assumed, though, that emigration from both countries correlated strongly during the second part of the 19th century.

\subsection{Harvests and pricing}

The pre-modern agricultural crises of the 19th century in Baden and Württemberg are known as agricultural crises of the "old type", characterized by an insufficient balance between population and harvests. After the strong beginning of industrialization in the second half of the 19th century and the following reduction of mass poverty, a "new type" of agricultural crisis developed, representing supply and sales crises of the second and third sectors (Abel, 1972). As early as the 19th century, pricing depended no longer just on the harvest of a product but also on the possibilities of selling it profitably. With the emergence of intermediate trade and wholesale and the improvement of import and export capabilities by faster transport routes and connections, local markets started to lose more and more importance, resulting in an ever-increasing dependency on large-scale trade flows.

Thus, the direct relation between crop yields and pricing decreased progressively. One of the main inflationary factors at this time was the so-called Fürkauf, a speculation sale of agricultural products purchased from the producers before the harvest, and thus removed from the local market. Although this development could also have had favorable effects with regional crop failures possibly being offset faster on larger markets - provided that capacity was available there, harvest yield remained the most important indicator for the development of prices for food and feed.

A comparison of emigration and price data shows a clear correlation: while high rates of emigration occurred during phases of massive price increases, emigration numbers were less significant during periods of price decrease. Figure 5 gives an overview of the development of average prices of cereals and the waves of emigration. During the course of the research, a further weather-sensitive indicator, the so-called "potato disease", which started to occur in the southwest of Germany in 1845, was discovered (see Sect. 5.3). It can be assumed that this disease repeatedly put further pressure on grain prices during subsequent decades. 
Grain: year average prices [100 kg] in Württemberg vs. emigration (1812-1886)

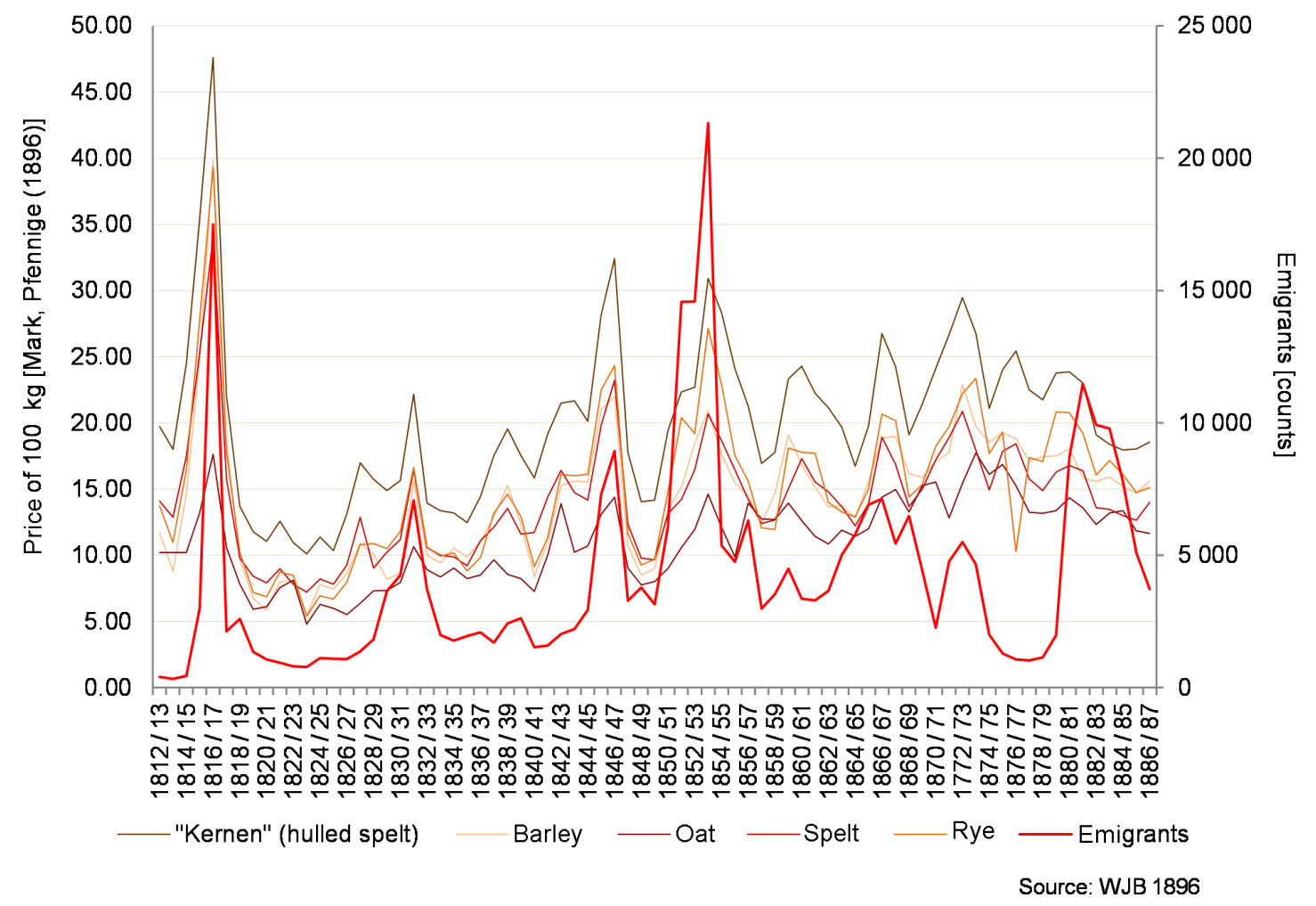

Figure 5. Comparison of grain prices and the number of emigrants in the kingdom of Württemberg (1812-1886).

\subsection{Climate development in the 19th century}

The general climate development for southwest Germany during the 19th century until the onset of the anthropogenically driven "greenhouse gas" climate of the 20th century is characterized by the ending of the LIA (see Fig. 6). In general, temperatures lay below the 20th century mean, precipitation was somewhat higher. Three major cooling periods and two major warming phases characterized the midterm trend, including a high year-to-year variability (see Glaser and Riemann, 2009; Glaser, 2013). Major glacier re-advances leading to pronounced lateral moraines in the alpine regions accompanied these cooling periods (Pfister, 1985; Grove, 1988). Additionally, several climatic extremes can be identified, such as the flood of 1824 which affected large parts of the study area (Bürger et al., 2006), as well as floods in 1882 and 1896 (Himmelsbach et al., 2015; Glaser et al., 2010), each one resulting from different underlying climatic causes. Further outstanding events like winter storms; extremely cold winters like 1831/32; the extreme droughts of 1834,1842 and 1853; or wet years like 1851 and 1878 and the extreme frost events in 1854 and 1883 caused casualties and devastated the land.

The evolution of the yearly mean temperature in Germany illustrates, on the one hand, a high year-to-year variability including extreme years such as the cold year of 1831 and, on the other hand, a medium-term decadal trend (orange) as well as the long-term trend (red). The latter clearly shows the decadal fluctuations at the end of the LIA and the transition into the modern "greenhouse gas" climate, especially pronounced since the 1970s (Glaser, 2013).

\section{The emigration peaks of 1812-1886 and their underlying climatological and socioeconomic causes}

To assess the climatic trigger of the identified main peaks of emigration (see Fig. 4), a first analysis focused on single peak emigration years. Subsequently, the associated waves of emigration were analyzed in more depth with respect to their variable climatic conditions as well as the socioeconomic and political background during the particular time periods.

Figure 7, first of all, shows the standardized event-specific variables for the peak years with the largest waves of emigration from Württemberg between 1816 and 1886. It illustrates the magnitude of the assumed influence of the observed variables on emigration by displaying the $z$ scores (see Eq. 1) of cereal prices during a year of high emigration as well as the seasonal STI and SPI for autumn, winter, spring and summer and the $z$ scores of crop yields 1 year before a high emigration year. 


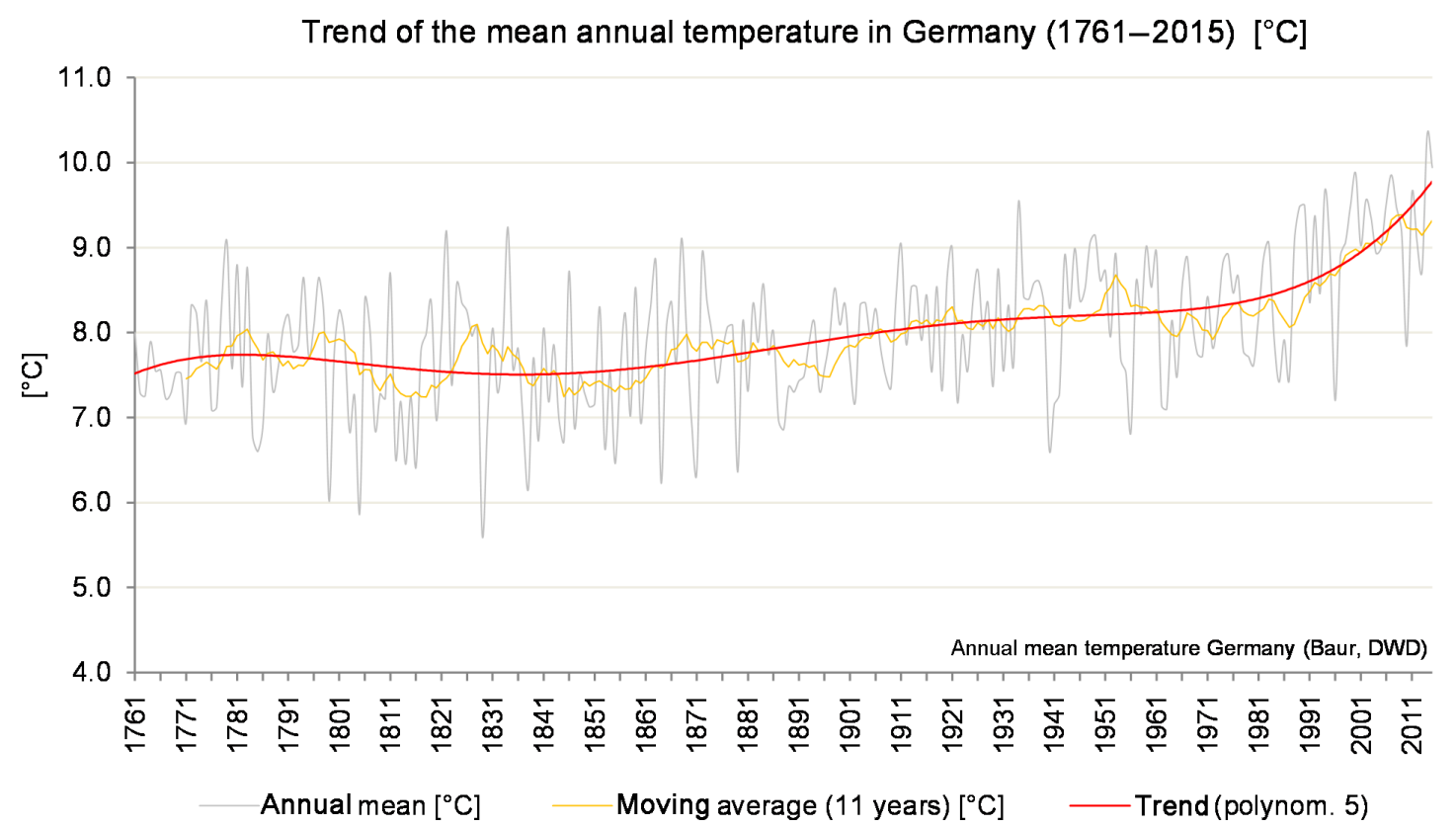

Figure 6. Evolution of the mean annual temperature in Germany (area average according to Baur and DWD).

The positive $z$ scores in Fig. 7 indicate "warmer temperatures", "higher precipitation", "higher crop yields" and "higher prices", whereas negative values by analogy indicate "lower temperatures", "less precipitation", "lower crop yields" and "lower prices". The $z$ scores show to what degree each parameter deviates from the long-term mean as a proportion of the standard deviation. For example, the STI of summer 1816 has a value of -2.83 , meaning that the mean temperature of summer 1816 falls below the mean of 1804 to 1886 by 2.83 -fold of the standard deviation. The decision to display autumn, winter, spring and summer values for temperature and precipitation was based on the necessity to consider the seasons separately as relevant growth (or vernalization) periods of the observed cereal types to cover all phenological phases.

By exposing the quantitative dimensions of these indicators presumed to be associated with the largest emigration waves, Fig. 7 clearly demonstrates that every emigration peak was characterized by a particular set of preconditions and subsequent effects. Focusing on the climatic parameters temperature and precipitation, these results suggest that there was no unidirectional impact of weather conditions. Specific similar tendencies may have had opposing effects depending on the different seasons. This could be observed for example in the case of the year 1846: while winter was mild and rather warm spring temperatures in combination with sufficient precipitation may have stimulated growth, the subsequent extraordinarily hot summer and a lack of rainfall may have been the crucial factors for the far too poor harvest in 1846 , and thus the rise in grain prices in the same and the following year.
Subsequently, the different waves of emigration including their single peak years and the assumed associated indicators, quantified by $z$ scores, are described within their economic and sociopolitical background.

\subsection{The emigration wave of $1816 / 17$ as a consequence of the "Year Without a Summer"}

One of the most prominent natural disasters of the 19th century was the massive eruption of Mount Tambora, located on the island of Sumbawa, Indonesia, between 5 and 10/11 April 1815 , causing the death of approximately 71000 people. Volcanic ash with an estimated volume of more than $150 \mathrm{~km}^{2}$ was expelled into the atmosphere, reaching heights of up to $50 \mathrm{~km}$. The eruption ejected roughly $60 \mathrm{Mt}$ of sulfur into the stratosphere, forming a global aerosol veil and obscuring the sun for more than 2 years. This caused pronounced global climate perturbations. Temperature decreases were observed for the northeast of the USA, in east Canada and in central Europe and resulted in the so-called "Year Without a Summer" in 1816 (Stommel and Stommel, 1983). Crop failures were widespread and, as a consequence, subsistence farming broke down and famine occurred (Oppenheimer, 2003; Behringer, 2016).

Temperature records from southwest Germany confirm this specific situation: the year 1816 was one of the coldest years of the century (Stuttgart, $1816: 8.10^{\circ} \mathrm{C}$, with only 1829 $\left(7.83^{\circ} \mathrm{C}\right)$ and $1879\left(8.09^{\circ} \mathrm{C}\right)$ being colder; Karlsruhe, 1816: $8.92^{\circ} \mathrm{C}$, with only $1805,1864,1871$ and 1879 being colder at $8.31{ }^{\circ} \mathrm{C}$; Basel, $1816: 7.2^{\circ} \mathrm{C}$, with 1805 and 1879 featuring the same lowest annual means in air temperature). The year 1816 is characterized not only by a below-average annual 

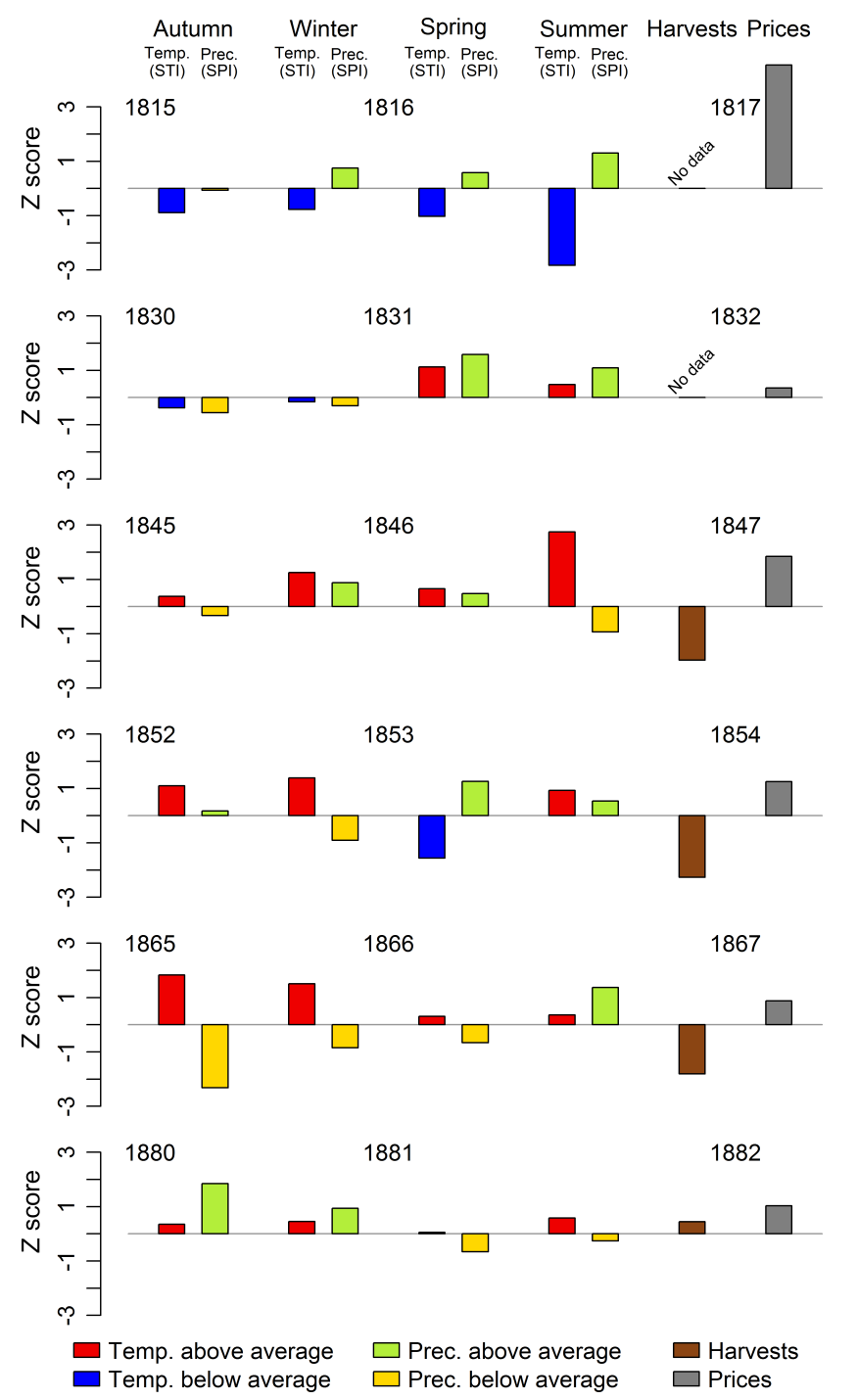

Figure 7. $Z$ scores of seasonal temperatures (STI), precipitation (SPI), harvests and prices of the peak years of emigration from Württemberg between 1816 and 1886. $Z$ scores indicate the proportion of standard deviation from the long-term mean.

mean temperature but also, more importantly, by the unfavorable distribution of temperature and precipitation during the growth period and the harvest season (see Fig. 8).

For both territories, harvests for 1816 were described as a "bad failure" (Stieffel, 1842; Dürr, 1895). To assess and understand the general societal and environmental conditions during this year, the preceding years have to be taken into account. No one was prepared to deal with this extreme year: the last full harvest dated back to 1812; since then granaries had not been filled sufficiently due to the Napoleonic Wars and marauding troops. It seemed that, due to the turmoil of war, large parts of the agrarian country were not cultivated during this period, which reduced the total harvests even more. As a consequence, a large fraction of the population was highly vulnerable with respect to food security. In addition, politicians reacted with a substantial and disastrous time lag: it was not until November 1816, and thus definitely too late, that tariff measures regulating import and export of grain were implemented.

In Württemberg, several thousand bushels of grain - worth 1.4 million guilders - had been exported instead of supplying domestic population. In October it was already too late for a government-initiated additional purchase of grain on foreign markets. It was not possible to deliver the urgently required goods to Württemberg or Baden before wintertime. Transport was severely impeded and obstructed by fast-freezing rivers with ice break-up taking place quite late in the following spring. Forage production also failed due to the wet and cold weather, leading to massive animal diseases. Hence, farmers sold their livestock in large quantities before wintertime. Initially, this caused a substantial decline of prices in the meat market, which turned into the opposite in the following spring (Gehlinger, 1897). According to official statistics, 22630 emigrants left the Kingdom of Württemberg between $1815 / 16$ and $1817 / 18$, with a peak of 17500 emigrants in $1816 / 17$. The municipalities in charge of provisioning the poor were forced to buy large amounts of grain from the royal granaries and consequently accumulated debts. This led to tax debts summing up to 8975783 guilders in the Kingdom of Württemberg alone. Between November 1816 and January 1817, the government of Württemberg imposed regulations to set up Wohltätigkeitsvereine (charitable societies). The Grand Duchy of Baden followed in March 1817 with the foundation of the "Allgemeinen Wohltätigkeitsverein für das Großherzogtum Baden zur Bewältigung der Auswirkungen des Krieges und der Mißernte" (Charitable Society for the Grand Duchy of Baden to Overcome the Impacts of War and Harvest Failures) under the auspices of the Grand Duchess Stephanie (1789-1860). In April 1817 export tariffs were further increased (Regierungsblatt Württemberg, 1817).

In Baden, income from tariffs was re-allocated to the suffering municipalities in February 1817. In June 1817 both countries prohibited the speculative sale of the upcoming grain harvest auf dem Halm (i.e., sale of growing crops before the harvest), and in Württemberg a census of all grain in stock took place, in the hope of triggering a decline in grain prices by demonstrating that there were sufficient provisions until the coming harvest (Regierungsblatt Baden, 1817). The case of the year 1816 shows how subsequent unfavorable seasonal tendencies within 1 year may have an amplifying effect (see Fig. 7): while mean spring temperatures were unusually low, the summer can be considered as extremely cold ( $z$ score: -2.83$)$ and quite wet ( $z$ score: 1.30$)$. These unfavorable conditions for crops ultimately contributed to a strong increase in cereal prices. In conclusion, the main reason for the crisis and famine of 1816 was the harvest failure in large parts of Europe due to the adverse climate conditions. This clearly demonstrates that the $1816 / 17$ migration peak was triggered by the climatic consequences of the Tambora erup- 
Climate Stuttgart 1816 and CLINO period 1961-1990

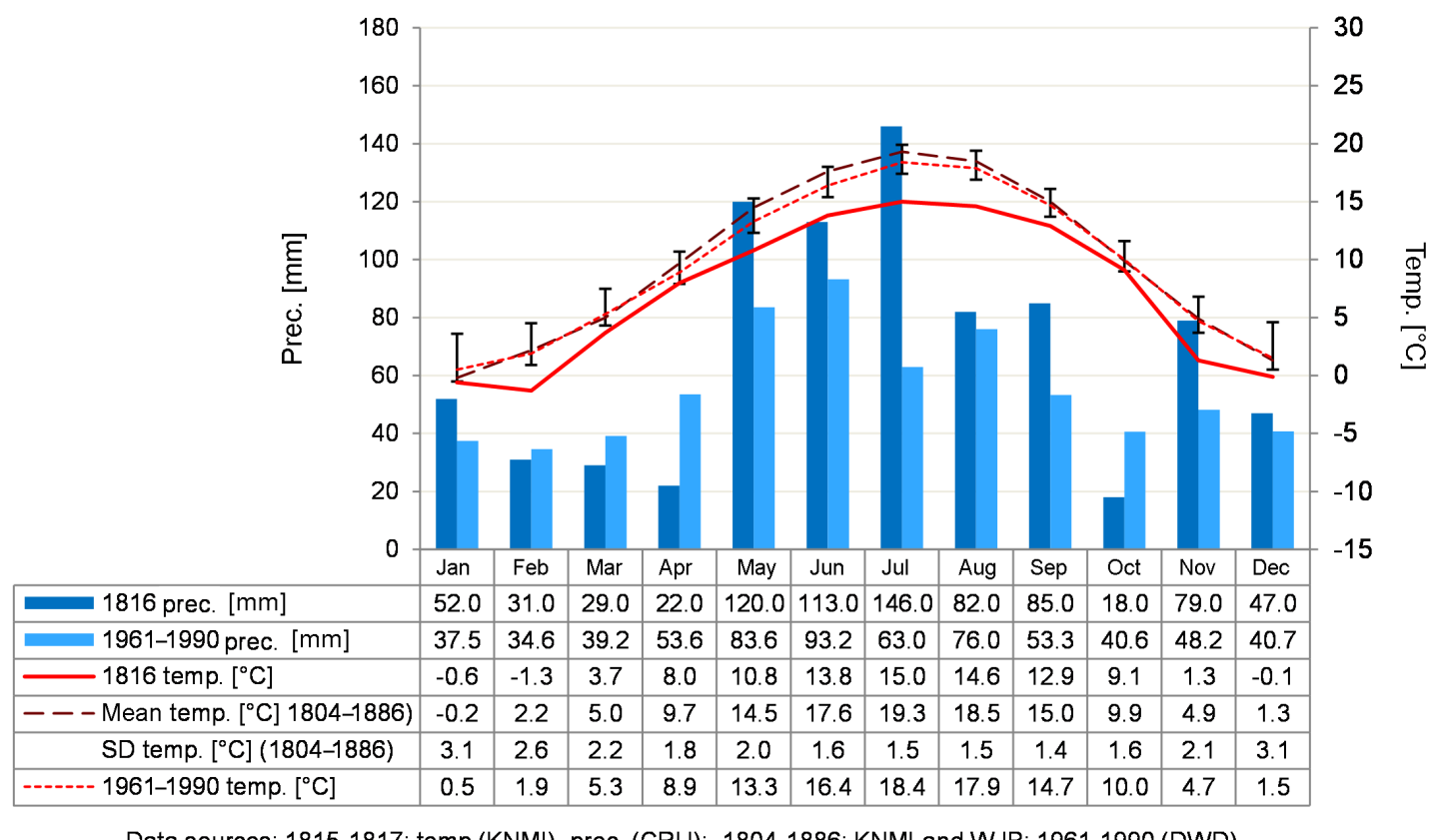

Data sources: 1815-1817: temp (KNMI), prec. (CRU); 1804-1886: KNMI and WJB; 1961-1990 (DWD)

Figure 8. Temperature and precipitation for Stuttgart for the year without summer (1816).

tion in 1815 , amplified by a number of the specific circumstances, like a lack of preparedness, harvest failures in the preceding years, the situation after the Napoleonic era and poor crisis management (von Memminger, 1818; Heünisch, 1857; Behringer, 2016).

\subsection{The emigration wave between 1829 and $1833-$ unfavorable weather conditions, harvest failure and} speculations

Between 1829 and 1833 the official number of emigrants from the Kingdom of Württemberg reached 18650 , with a peak of 7066 emigrants in 1831/32 (see Fig. 4).

Regarding the climatic conditions, these years were not particularly anomalous; a notable exception was, however, the severe winter of 1829/30, which featured 112 ice days (today: frost days) in Stuttgart and 92 in Karlsruhe, and was one of the longest and coldest winters since 1788. On 2 February, the cold reached $-32^{\circ} \mathrm{C}$ in Stuttgart and Tübingen, and in Tuttlingen even $-35^{\circ} \mathrm{C}$. Even in 1788 temperatures had not been as low (WJB, 1830).

The following year, 1831, was characterized by just slightly higher temperatures compared with the whole evaluation period (see Fig. 7, $z$ scores: 1.12 and 0.48), whereas precipitation rates during spring and summer were rather high ( $z$ scores: 1.58 and 1.09). However, a possible influence on crop yields for this time period cannot be established quantitatively, as crop data were not available for years prior to 1846 (see Sect. 3).
The harvests of 1830 and 1831 in Baden were described as mangelhaft (deficient), whereas in Württemberg, they were qualified as mittelmäßig (fair) and noch ziemlich ergiebig (still quite productive) (Stieffel, 1842; Pfaff, 1846). Nevertheless the situation in Stuttgart deteriorated so much that soup kitchens for the poor had to be opened. In addition to the insufficient harvest result, documentary sources point at another major reason for the soaring grain prices which triggering the emigration: it was found in market speculations rather than in harvest failure. Even contemporaries could not see any connection to harvests in 1832 . Instead, speculations of wholesale and intermediary vendors were considered to be responsible for the development of grain prices (Pfaff, 1846, p. 351; Freiburger Zeitung, 1832).

\subsection{The emigration wave of 1845-1848 with the peak years 1846/47 with a hot and dry summer, low crop yields, high prices and the specific situation of the potato disease}

In the Kingdom of Württemberg, the number of emigrants had already been increasing since the year 1843/44. Between 1845 and 1847,16244 persons emigrated according to official statistics (see Fig. 4).

Regarding the climatic conditions of these years, the summer 1845 was generally wet with an extensive period of rain in June. In 1846 an exceptionally hot (see Fig. 7, $z$ score: $2.75)$ and dry summer $(z$ score: -0.93$)$ occurred with abnormally low precipitation rates during May and June (see 
Fig. 9). This resulted in low crop yields (see Fig. 7, $z$ score: $-1.97)$ and led to strikingly high cereal prices ( $z$ score: 1.85 ) in the subsequent year of 1847 .

Harvests for the years 1843 to 1845 in the Kingdom of Württemberg are described as nicht so ergiebig (not abundant) for winter wheat, but for spring wheat as den Erwartungen entsprechend (according to expectations) (WJB of the years 1843-1845). In the Grand Duchy of Baden, harvests in 1843 are labeled as mittlere Ernte (average yield), in 1844 the harvest was labeled reich und gut (rich and good) and in 1845 the weather was characterized as sehr fruchtbar (very fertile). Nevertheless, according to other reports for 1845 , the grain harvest yield was below average (Fleischmann, 1902). In 1846 the crop yields in Baden were good only for oat and barley, the results for wheat and rye were considered poor and those for spelt (the most important bread grain) as average (Fleischmann, 1902). In Württemberg, both winter and spring wheat harvests resulted in only mediocre yields (WJB, 1846, 1). Insufficient yields were mainly recorded in areas characterized by unfavorable edaphic and climatic conditions, such as the Jura of Swabia, Odenwald, or the Black Forest.

While the grain yields seem to have been average to fair, another basic food product came under pressure: in 1845, the potato disease appeared in Württemberg and Baden for the first time. Recent research concerning the origin of this disease shows that it was first observed in Belgium in June 1845 and spread out from there throughout central Europe and its southern parts until September. It is still unclear whether it was brought to Europe from North or South America by seeds. In Ireland, this blight caused an extreme famine and in consequence an exceptionally high emigration peak because of the one-sided dependence on the potato plant and crop failures of up to $90 \%$; while this fungal infection was completely specified in 1861 , an operative fungicide was not developed before 1888 (Herrmann, 2011).

Figure 10 shows the time series of the annual harvest of the main potato crop and the precipitation during their growth period between April and September (6-monthly SPI of September for Stuttgart) after the first appearance of the potato disease in 1845 . The inverse development of both time series indicates that during wetter years, i.e., years with a higher SPI, a higher percentage of potatoes fell victim to blight.

To understand the vast impact of the potato disease, especially for the Kingdom of Württemberg, one has to consider that an increasing number of factory workers also acted as part-time farmers at this time, favored by the partible inheritance system. These subsistence economy activities in horticulture and agriculture on small inherited plots played a crucial role in ensuring food security. Potato cultivation in particular was widespread because the plant was well suited for such activities due to the relatively small expenditure of work and its modest edaphic requirements. As a consequence, as from autumn 1845, the potato harvest failure resulted in a huge pressure on grain prices not only in the cities but also in the rural areas (Megerle, 1982). The potato disease of 1845 was not unique, appearing repeatedly until the 20th century in varying degrees of intensity, accordingly affecting crop prices.

Additionally, both Baden and Württemberg had completely lost freedom of action regarding tariffs on grain after joining the "Deutsche Zollverein" (German Customs Union), making it impossible to implement any measures to restrict the export of grain if the other members of the union denied such plans. Only a temporary ban on the export of potatoes could be arranged within the Deutsche Zollverein (Centralstelle des Landwirtschaftlichen Vereins Karlsruhe, July/August 1845). In the following spring, potatoes started to grow well and, as a consequence, the export ban was released. However, the dry summer of 1846 was again unfavorable to the growth of the crop. Additionally, the late blight spread into hitherto unaffected areas of Württemberg. In Baden, areas with unfavorable edaphic and climatic conditions suffered again from potato harvest failures. Collections of the charitable societies dedicated to these regions were carried out as of 1847 (Freiburger Zeitung, 1847b). In the municipalities, which were still responsible for the relief of the poor, soup kitchens were re-opened already in autumn 1846 (Freiburger Zeitung, 1847c).

The increase in grain prices reached its peak between April and May 1847. As of the beginning of May, riots caused by hunger occurred in the cities of Ulm, Tübingen and Stuttgart (Kingdom of Württemberg) and also in Mannheim and Villingen (Grand Duchy of Baden) (Brüning and Exner, 2007; Dürr, 1895). At this point, the governments of both countries again initiated a census of existing food stocks to show that there were sufficient provisions and to calm down the markets in order to level out prices, at least until the coming harvest (Regierungsblatt Württemberg, 10 May 1847 and Freiburger Zeitung, 1847a). In both countries, these activities were successful along with further regulations

In summary, it can be said that although the rather warm spring temperatures in 1846 in combination with sufficient precipitation still may have been stimulating growth, the extraordinarily hot summer with a lack of rainfall seems to have been the crucial factor for the far too poor harvest. In consequence, prices for cereals increased strongly in the same and the following year. We assume that the almost complete failure of the potato harvests between 1845 and 1847 additionally increased the pressure on grain markets. This represents a further indication that the migration of these times has mainly been triggered by unfavorable climatic conditions via their effects on harvests and prices.

\subsection{The biggest emigration wave between 1850 and 1855 - low harvests, war and administrative support}

During the biggest emigration wave from 1850 up to the end of 1855, a total of 61944 people from Württemberg and 
Climate Stuttgart 1846 and CLINO period 1961-1990

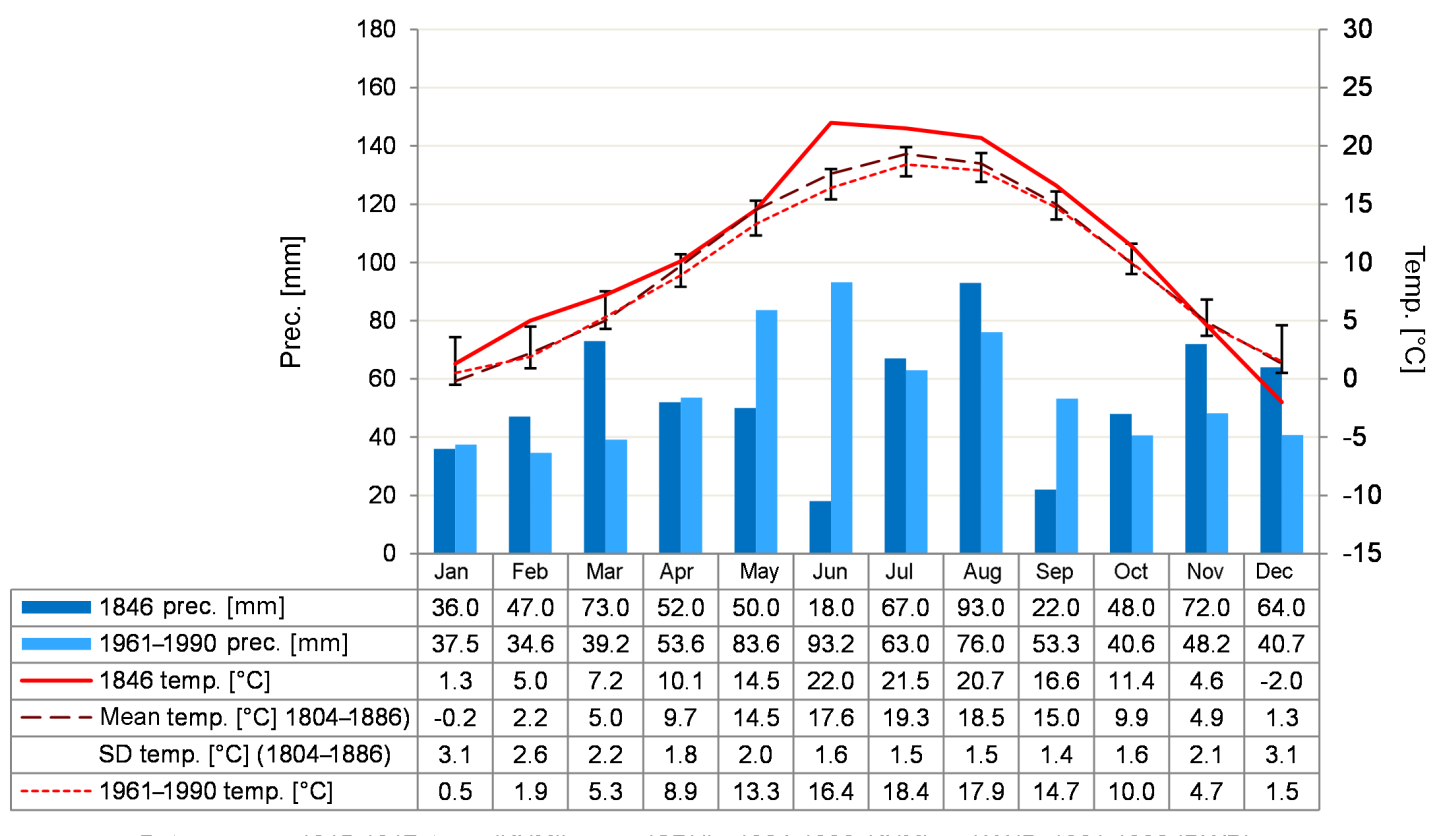

Data sources: 1815-1817: temp (KNMI), prec. (CRU); 1804-1886: KNMI and WJB; 1961-1990 (DWD)

Figure 9. Temperature and precipitation for Stuttgart (1846).

\section{Precipitation summer half year (SPI 6_Sept, Stuttgart) and potato harvest $(1848-1886)$}

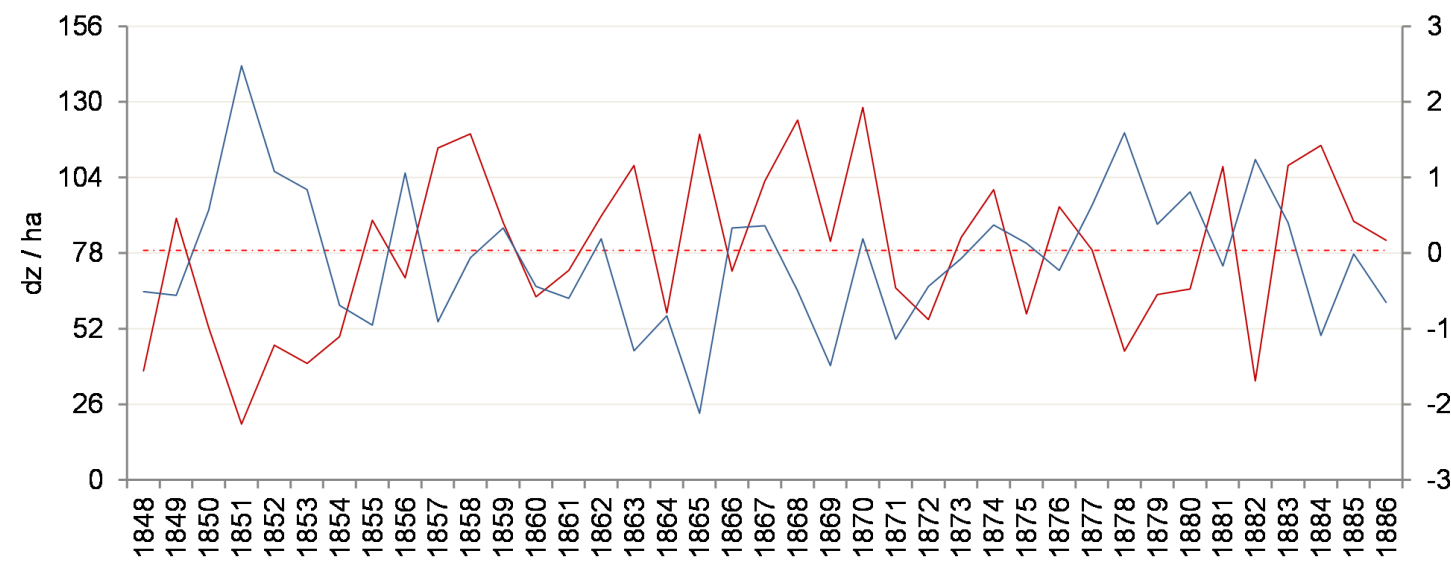

Potato harvest

Average potato harvest (1848-1886)

SPI_6_Sept Stuttgart

Figure 10. Potato harvest in Württemberg and the precipitation index for April-September (Stuttgart, 1848-1886).

60606 people from Baden left their countries. The main peak was reached in 1853/54, when 21320 (Württemberg) and 21561 people (Baden) emigrated. No other period within the 19th century reached this dimension (see Fig. 4).

In the summer of 1850 , the weather tended to be damp and cool, reflected by the marginal number of 25 summer days in Heilbronn and Stuttgart. The following summer of 1851 was also unusually humid, with only 32 summer days in Heilbronn and 23 in Stuttgart.
The winter of $1851 / 52$ led to famines in the climatically least favored areas of Odenwald and Black Forest (particularly in the counties Pforzheim, Waldshut, Säckingen, Schönau, Sankt Blasien and Wolfach). The support commissions again resumed their commitment: donations were collected and soup kitchens were re-opened (Fleischmann, 1902). In 1852 the months of August and September were wet again. In 1853, an unusually cold (see Fig. 7, $z$ score: -1.53 ) and wet ( $z$ score: 1.26$)$ spring was followed by a moderate sum- 
Table 1. Total financial support from the state, communities and private persons for the emigration from the Grand Duchy of Baden 1850-1855 (Fies, 2010).

\begin{tabular}{rrrr}
\hline Year & $\begin{array}{r}\text { Number of } \\
\text { Emigrants }\end{array}$ & $\begin{array}{r}\text { Financial support } \\
\text { (florins) }\end{array}$ & $\begin{array}{r}\text { Per person } \\
\text { (florins) }\end{array}$ \\
\hline 1850 & 2338 & 54090 & 23 \\
1851 & 7913 & 264614 & 33 \\
1852 & 14366 & 456706 & 32 \\
1853 & 12932 & 224613 & 17 \\
1854 & 21561 & 516688 & 24 \\
1855 & 3334 & 85072 & 26 \\
Total & 62444 & 1601783 & ca. 26 \\
\hline
\end{tabular}

mer ( $z$ scores: 0.93 and 0.54 for STI and SPI, respectively); crop yields were below average $(z$ score: -2.27$)$ and cereal prices slightly increased ( $z$ score: 1.25$)$ during the following year.

With the outbreak of the Crimean War (1853-1856) France changed its customs regulations, banning the export of food and abolishing import tariffs. Hereafter, particularly Swiss buyers turned their attention to the Baden grain markets, putting a strong pressure on grain prices.

In 1854 , when harvest yield was again only average, the effects of the protective customs regulations, which had been imposed by France, Russia and the other war-participating European states due to the Crimean War, became clearly apparent. The United States of America, which had always been a good alternative for grain purchases, was now also involved in the Crimean War and did not have any transport ships available. Therefore, prices remained at a high level, even after the rich harvest of 1855 , as no stocks existed due to the difficult previous years (Fleischmann, 1902).

The specific feature of these years lies above all in the fact that the Grand Duchy of Baden - as the only country at this time - acted according to an "emigration concept" to get rid of "the poor" by paying for their emigration. This practice was pursued for years, thereby encouraging emigration (Hansen, 1976; Fies, 2010). Besides the state, communities and private people also financed this kind of emigration (see Table 1).

In consequence of the financial support by the government, the population decreased between 1852 and 1855: in 1852, 1357208 people lived in Baden; by 1855, despite an excess of 14347 births, the population had decreased by $3.12 \%$. Official agencies ascribed this decline to emigration alone, proving the success of the policy practiced. The support of emigrants in the Grand Duchy of Baden did not stop completely after 1855 , but it was limited to isolated cases and single municipalities (Statistisches Jahrbuch für das Großherzogtum Baden, 1868 ff.).

All these facts indicate that this largest emigration wave was triggered by a number of reinforcing factors: on the one hand, the unfavorable climatic conditions and a subsequent harvest failure again caused price increases; on the other hand, the emigration policy of the Grand Duchy of Baden financially supported and thus fostered emigration. Additionally, the whole situation was negatively influenced by the overall geopolitical situation, with the Crimean War hindering the usual trading system.

\subsection{The emigration wave between 1863 and $1869-$ warm and dry weather conditions}

During a smaller, but longer-lasting, secondary emigration wave from 1863 to 1869 , a total of 36770 people emigrated from Württemberg and 16033 people from Baden. For the years after 1866, this emigration can mainly be explained by a further rise in occurrences of the potato disease in Württemberg (WJB, 1866 ff.). Additionally, frost at lower altitudes is reported for Württemberg for 23 May 1866, resulting in a significant loss of winter crops (WJB, 1866).

Regarding temperatures, the year 1866 was average (see Fig. 7, spring $z$ score: 0.31 and summer $z$ score: 0.36 ); however, spring was slightly dry $(z$ score: -0.66$)$ and summer rather wet ( $z$ score: 1.37 ), with especially the wet July being responsible for a frequent appearance of the potato blight (Dürr, 1895). Crop yields developed significantly below average ( $z$ score: -1.87 ). Also, in the subsequent year of 1867 , the grain harvest in Württemberg remained behind the previous 10 years' average, which is attributed mainly to the cool and rainy months of June and July (Dürr, 1895). In consequence, the cereal prices ( $z$ score: 0.88 ) increased slightly. Despite these weather conditions, only $4 \%$ of the potatoes in Württemberg were affected by the disease and the potato harvest was yielded more than in 1866 (WJB, 1867).

In a climatologically broader context, the emigration between 1863 and 1869 fell into a phase of warmer temperatures (see Fig. 6), with quite inconsistent weather conditions during this whole period. In summary, the year 1863 was too dry and in parts too warm for effective crop production. Of particular note is the 6-week drought starting in July, with rain not returning until September. Heat and drought also characterized the subsequent summer of 1864, while the winter of 1864/65 was considered as long, lasting until the end of March. Then again, the weather became exceptionally warm, with some periods even hot. The number of summer days was accordingly high (103 days in Stuttgart and 57 days in Heilbronn). The following year, 1866, can be classified as rather average with a warm, early summer, a wet August and a very dry October. The next winter, 1866/67, was mild; in 1867, May was very dry and warm, June and July were, however, exceptionally cold and humid, and August was again unusually hot. In autumn, drought struck again. The year 1868 was generally too warm and dry. In 1869, the weather was again very contradictory with respect to hygric as well as thermic conditions, with February being very warm, March being rather cold, April and May again exceptionally warm, and June, conversely, too cold; then it was very hot again until 
mid-August, while the second half of this month was rainy and chilly.

Interestingly, in this specific period of emigration, not one specific form of adverse weather conditions but rather the dichotomy of the conditions of several subsequent seasons influenced harvests negatively. In combination with slightly increased market prices, these can be considered as a substantial cause of the emigration peak of 1866/67.

\subsection{The emigration wave between 1880 and $1886-$ attraction of the "New World" and family reunifications}

In the last striking emigration wave between 1880 and 1886, a total of 54776 people emigrated from Württemberg and 18822 people from Baden (see Fig. 4).

The year 1880 began with a severe winter and continued with a "beautiful" spring. Of particular note was the rainy period from late September on, which led to two smaller Neckar floods on 20 and 28 October. The year 1881 brought a good, above-average harvest (see Fig. $7, z$ score: 0.44) and was, apart from a cool January and October and hot July and August, marked by average temperatures ( $z$ score spring: $0.05, ; z$ score summer: 0.58). January, May, November and December were exceptionally dry ( $z$ score spring: -0.66 ; $z$ score summer: -0.26$)$. Even though climatic conditions and harvests were quite good, cereal prices increased ( $z$ score: 1.03) in 1882, the year with peak emigration.

The year 1882 began with snow and ice that lasted until mid-February. After a warm start of April, there was renewed snowfall. June and July were rather wet. Moreover, this year was particularly noteworthy since it was characterized by two extreme flood events in Württemberg and Baden in November and at the end of December. 1883 was remarkable with regard to a cold spell mid-March onwards and high humidity in July. Although this did not diminish the abundant harvest of potatoes in this year, the entire harvests remained somewhat below those of previous year. Climatically, 1884 was an almost average year which was a little warmer in spring and generally drier than on average. The year 1885 brought a rich harvest of potatoes and, at the regional level, strongly differing crop yields. One may highlight the cold and quite humid months of May, August and October. In 1886, the harvest was a bit lower than average and grain had to be imported. It was cold up to 20 March; summer was warm and pleasant and lasted until mid-September, and autumn also remained mild until 20 December. Subsequently, very strong snowfall occurred, bringing everyday life to a standstill.

From the climate perspective, no special causes can be identified for an increase in emigration. By this time, world food markets were better interconnected and more effective. As of the founding of the German Empire in 1871, consistent trade and customs measures existed, which means that there were enough and better buffering capacities to balance out short-term regional food shortages. The construction boom, which started shortly afterwards, and the expansion of the public sector brought more job opportunities, e.g., in railway and post service, river training and road construction. Overall, a strong increase in the food sector's resilience against climatic influences on regional crop yields can be noticed.

Looking for a major reason for this emigration wave, current research stemming from a more societal point of view concludes that the "attraction of the New World" as a whole and the "reunification" of successfully emigrated family members were the main drivers (Fies, 2010).

\section{The long-term influence of unfavorable climate, crop failure and increased prices on emigration}

All major waves of emigration and single emigration peaks from southwest Germany into North America revealed a chain of effects consisting of unfavorable climatic conditions $\rightarrow$ poor crop yields $\rightarrow$ rising cereal prices $\rightarrow$ emigration. The long-term correlations of these parameters were assessed quantitatively by the following models:

1. Cereal crop yields $\sim$ STI + SPI: a linear model of mean annual cereal crop yields (mean of wheat, barley, oat, spelt and rye) as a function of the 6-monthly STI and the 6-monthly SPI (considered as descriptors for weather conditions during the course of the previous 6 months) was constructed for the time interval of 1846 1885. The strongest effect could be identified for the 6monthly STI of February and the 6-monthly SPI of August as predictor variables. The model was significant $\left(\mathrm{F}(2,37)=7.12, p<0.01\right.$; adjusted $\left.R^{2}: 0.24\right)$, with both predictors being significant $(p<0.05)$. Both predictors had a negative effect on the response variable.

The model explains about $24 \%$ of the variance of cereal crop yields, with the SPI accounting for the major proportion. This indicates a slightly positive effect of colder temperatures during preceding autumn and winter (September to February), especially for winter wheat and winter barley, and a stronger, negative effect of wet conditions during the growth period (in this case March to August) on the total crop yields.

2. Potato crop yields $\sim$ STI + SPI: a further linear model of potato crop yields as a function of the STI and the SPI was constructed for the time interval of 18461885. The strongest effect could be identified for the 6-monthly STI of September and the 6-monthly SPI of August as predictor variables. This model was significant $\left(\mathrm{F}(2,37)=6.35, p<0.01\right.$; adjusted $\left.R^{2}: 0.22\right)$ with the SPI as significant predictor $(p<0.05)$ and both predictors accounting for each about $10 \%$ of the variance.

This model demonstrates a positive effect of the STI and a negative effect of the SPI on crop yields, which was interpreted as a general increase in the potato harvest with warm and dry weather conditions during April 


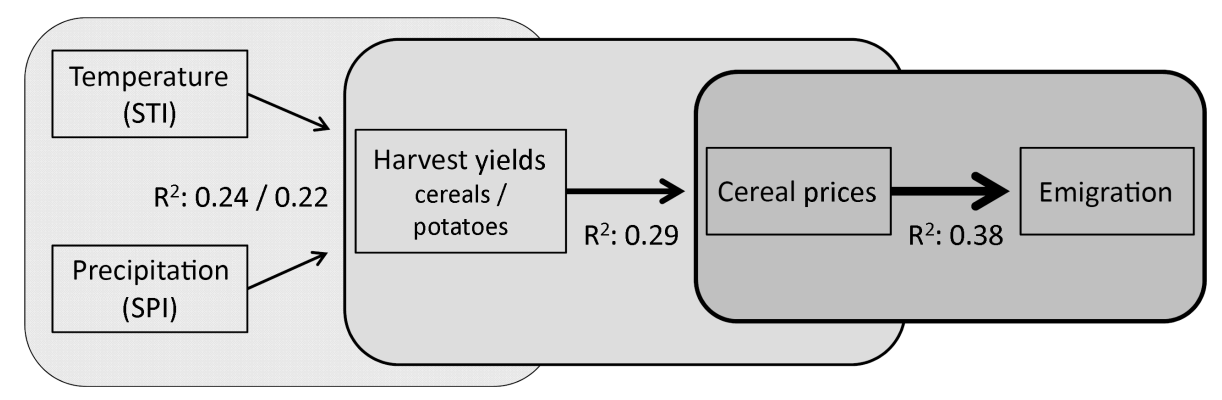

Figure 11. Chain of effects on emigration in the kingdom of Württemberg with corresponding coefficients of determination.

to September. This may have been linked to the severe reduction of the potato harvest in years of high prevalence of the potato disease which seems to have been enhanced by wet conditions (see Sect. 5.3).

3. Cereal prices $\sim$ cereal crop yields: a significant negative effect of mean cereal crop yields (1846-1885, mean of the crops of barley, oat, spelt and rye) on mean cereal prices of the subsequent year (1847-1886, mean of the prices of barley, oat, spelt and rye) could be identified by a linear model $(\mathrm{F}(1,38)=16.83, p<0.001$; adjusted $R^{2}: 0.29$ ). This was understood as a confirmation of the obvious link between price increases due to supply shortages. A temporal offset of 1 year emerged for the influence of crop yields on cereal prices, meaning that the effect on cereal prices in the same year was comparably smaller than in the following year.

4. Migration $\sim$ cereal prices: finally, a generalized linear model was used to assess the effect of cereal prices (mean of the prices of barley, oat, spelt, rye and hulled spelt (Kernen)) on migration numbers within the time interval 1816-1886. A negative binomial regression model was chosen (Venables and Ripley, 2002) due to the distribution of the response variable "migration". This model was significant $(p<0.001)$ and shows that about $38 \%$ of the variance of migration numbers between 1816 and 1886 can be explained by the cereal price trend (see Fig. 4, Sect. 4.2). No considerable overdispersion was found. The years 1818, 1819, 1849 and 1854 were identified as influential data points by Cook's distance (Cook and Weisberg, 1982; Williams, 1987). Nevertheless, after excluding these points from the analysis, the model was still significant $(p<0.001)$ with $R^{2}=0.38$. Years with higher emigration rates were mostly accompanied by above-average cereal prices. The resulting pressure of food scarcity on individuals was considered as one important reason for emigration.

For all of the presented models, the residual plots were checked visually, without finding indications of violations of linearity, homoscedasticity or normality. The assumption of a normal distribution of the residuals was also not rejected by the Shapiro-Wilk normality test (Gross and Ligges, 2015).

The results of these models (Fig. 11) demonstrate weak to moderately strong effects and can be considered as a validation, albeit at different degrees, of the assumed influences of temperatures and precipitation on crop yields, of crop yields on the development of cereal prices and finally of the influence of cereal prices on emigration numbers from southwest Germany during the 19th century. Thereby, the positive correlation between cereal prices and migration numbers was strongest, followed by the effect of cereal crop yields on cereal prices (negative correlation).

Of specific interest are certainly models (1) and (2) as they refer to direct climatic effects on harvests. A closer observation of these models suggests that rather wet climate conditions during growth and ripening period - over the long term - tend to imply lower harvests, while drier conditions in spring and summer are associated with richer harvests; this applies to cereals as well as to potatoes. Concerning temperatures, however, the effect of vernalization (see Sect. 3), the requirement of a persistently cold period during winter, is obviously essential for cereal harvests, as expressed in model (1). This does not imply an irrelevance of temperatures during the growth period, but it may indicate a relatively higher importance of the vernalization process for the harvests. In contrast, the strongest climatic effect on potato harvests can be seen in a positive correlation between spring and summer temperatures and harvests.

For the interpretation of these results it is important to be aware that these linear models represent a quantitative assessment of tendencies, i.e., directionality and strength of effects over the long run. This statistical tool provides a further, more generalized long-term perspective additional to the assessment of individual years of peak migration (Fig. 7). Climatic conditions during some of the years described in Sect. 5 were at times extreme. They deviated so much from the mean that they exceeded the general trends described in models (1) and (2) and had an adverse effect on plant growth. This is not a contradiction but rather an expression of the climate variability. 


\section{Discussion and conclusion}

The overall goal of this study was to analyze and quantify to what extent climate triggered migration from the German southwest to North America in the 19th century. So far, the broader discussion has mainly been dominated by aspects concerning the political, economic, agricultural and religious situation and the population development itself (Bayer, 1966; Abel, 1972; Megerle, 1982; von Hippel, 1984; Scheuerbrandt, 1985; Tuchtenhagen, 1999; Meier-Braun and Weber, 2009) and, additionally, the situation in the target regions (Oltmer, 2010) and family networks (Fies, 2010) were taken into consideration. Only for specific years like 1816/17 climate was identified as a main reason for migration (e.g., Krämer, 2015; Behringer, 2016; Brázdil et al., 2016). In the modern discussion on the impact of climate change, migration is, however, regarded as a major topic on a global scale (IPCC, 2014). Yet, most of the results describing the interaction between climate and societies are not quantitative.

In our approach we first analyzed empirically population development, emigration data, climate development, harvests and prices for the whole evaluation period and identified long-term interactions and correlations between these parameters statistically. The centennial trends for the different parameters display a nearly constant growth of population, strong fluctuations in emigration numbers, the LIA variations in climate and a slight increase in prices which is characterized by high mid-term rises. For a statistical evaluation of a long-term influence of climate on emigration, linear modeling was applied to the available numerical data, covering the time period of 1846-1886 (see Sect. 6). The models show that the climatic variables temperature and precipitation explain $24 \%$ of the total variation in grain harvests and $22 \%$ of potato yields. Cereal crop yields, in turn, account for $29 \%$ of the total variation in cereal prices, and cereal prices for $38 \%$ of the variation in the variable emigration. The quantification of the relationships between these variables and their interlinked dependencies confirm the initial hypothesis of the considerable influence of weather conditions on harvests and the subsequent effects on emigration from southwest Germany during the second half of the 19th century.

Secondly, the migration data clearly revealed six larger waves of emigration (1816-1817, 1829-1833, 1845-1848, 1850-1855, 1863-1869, 1880-1886) by means of significant deviations from the long-term trend. Most prominent are the waves of 1816-1817 and 1850-1855.

Thirdly, we selected the peak years of these emigration waves, including the preceding years to cover the growth period of the main crops $(1816 / 17,1831 / 32,1846 / 47,1853 / 54$, $1866 / 67,1881 / 82$ ) and documented the overall societal, political and economic situation during these peak years. Standardized indices and $z$ scores were determined for climate, harvests and pricing (see Sect. 5). A closer look at the larger emigration waves and particularly the specific peak years indicates that they emerged out of complex reasons which oc- curred in each case in a specific combination. Hence, various factors came into play, which increased the willingness and motivation for large numbers of people to emigrate: in general, society had a positive attitude towards emigration during the considered decades, and administration even encouraged this financially, like in the 1850s in the Grand Duchy of Baden (see Sect. 5.4). Towards the end of the 19th century, the resilience against climatically adverse seasonal conditions was strengthened by more efficient trading routes and better access to food markets, finally reducing the climatic impact on migration (see Sect. 5.6). Apart from that, climatic conditions had a substantial indirect influence on emigration, as climate is a crucial factor for growth conditions and the ripening process of diverse crops, subsequently influencing price developments on the food markets - depending on supply and demand.

Regarding the evaluation period of 70 years (1816-86) it turned out, however, that the influence of the assumed chain of effects "climate $\rightarrow$ harvests $\rightarrow$ prices" was not equally pronounced with regard to the different peaks of emigration (see Sect. 5): the peak year of 1816/17 appears to be the most climatically influenced, in the sense that temperatures constantly decreased during the growth period from autumn 1815 to summer 1816 and, concurrently, precipitation amounts were increasing. This is the only migration peak year with such a clear climatic pattern. Moreover, the subsequent increase in prices is the most prominent, as the already existing food shortage was aggravated by delayed political reactions, which in turn intensified the food supply crises, and thereby triggering emigration. The peak year of 1830/31 was more dominated by higher temperature and precipitation during spring and summer, but it was also influenced by massive market speculations. The peak year of 1845/46 was predominantly characterized by an extremely hot and quite dry summer leading to bad harvests and high prices. The situation was furthermore aggravated by the first outbreak of the potato disease. In the peak year of 1852/53, a warm autumn and winter were followed by a cold and wet spring, leading to bad harvests and rising prices. The peak of 1865/66 shows dry and warm conditions during autumn, winter and spring, turning into a wet summer which obviously caused low harvests. The last peak year of $1881 / 82$ was more dominated by sociopolitical factors, especially the importance of family networks. During this period, weather conditions were not outstanding (a wet and somewhat mild autumn and winter) and led to a slightly above average harvest.

All in all we identified, analyzed and quantified the role of climate within a larger frame of multifold factors leading to migration without falling back into climate or natural determinism. The climate stressors like cold wintertimes, droughts, rainy seasons or summer heat can be regarded as indirect influences on migration during the analyzed periods and peak years by triggering a reaction chain via harvest results and pricing. 
Data availability. Model results of this study are available from the corresponding author upon request (ruediger.glaser@geographie.uni-freiburg.de). For access to historical sources see https://www.tambora.org/ (Tambora, 2017).

Competing interests. The authors declare that they have no conflict of interest.

Acknowledgements. This analysis was conducted within the research project "Climate of migration" (2010-2014), which was sponsored by the German Federal Ministry of Education and Research. Moreover, we would like to thank the reviewers for their constructive remarks and suggestions. The article processing charge was funded by the German Research Foundation (DFG) and the University of Freiburg in the funding program Open Access Publishing.

Edited by: Dominik Fleitmann

Reviewed by: two anonymous referees

\section{References}

Abel, W.: Massenarmut und Hungerkrisen im vorindustriellen Deutschland, Vandenhoeck \& Ruprecht, Göttingen, Germany, 83 pp., 1972.

Bauernfeind, W. and Woitek, U.: The Influence of Climatic Change on Price Fluctuations in Germany During the 16th Century price revolution, in: Climatic Variability in Sixteenth Century Europe and Its Social Dimension Climatic Change, edited by: Pfister, C., Brázdil, R., and Glaser, R., Special Volume 43, 303-321, 1999.

Bayer, D.: O gib mir Brot. Die Hungerjahre 1816 und 1817 in Württemberg und Baden, Deutsches Brotmuseum e.V., Ulm/Donau, Germany, 132 pp., 1966.

Beguería, S. and Vicente-Serrano, S. M.: SPEI: Calculation of the Standardised Precipitation-Evapotranspiration Index, R package version 1.6, available at: http://CRAN.R-project.org/package= SPEI (last access: 31 January 2017), 2013.

Behringer, W.: Tambora und das Jahr ohne Sommer, C. H. Beck, München, Germany, 2016.

Birkmann, J.: Measuring vulnerability to natural hazards: Towards disaster resilient societies, United Nations Univ. Press, New York, USA, 686 pp., 2013.

Borcherdt, C., Grimm, I., Rieger, G., and Strohal R.: Führer durch die Agrarstatistiken der südwestdeutschen Länder 1850-1939, Vol. 2., St. Katharinen, Germany, 742 pp., 1989.

Bortz, J. and Schuster, C.: Statistik für Human- und Sozialwissenschaftler, 7. Auflage, Springer, Berlin, Heidelberg, New York, 2010.

Boyd J. D.: An Investigation into the Structural Causes of GermanAmerican Mass Migration in the Nineteenth Century, PhD Thesis, Cardiff University, Cardiff, Wales, 2013.

Brázdil, R., Řezníčková, L., Valášek, H., Dolák, L., and Kotyza, O.: Climatic effects and impacts of the 1815 eruption of Mount Tambora in the Czech Lands, Clim. Past, 12, 1361-1374, https://doi.org/10.5194/cp-12-1361-2016, 2016.
Brüning, R. and Exner, P.: Wege aus der Armut. Baden in der ersten Hälfte des 19. Jahrhunderts, Förderverein des Generallandesarchivs Karlsruhe, Karlsruhe, Germany, 2007.

Büntgen, U., Tegel, W., Nicolussi, K., McCormick, M., Frank, D.; Trouet, V., Kaplan, J. O., Herzig, F., Heussner, K.-U., Wanner, H., Luterbacher, J., and Esper, J.: 2500 Years of European Climate Variability and Human Susceptibility, Science, 331, 578582, https://doi.org/10.1126/science.1197175, 2011.

Bürger, K., Dostal, P., Seidel, J., Imbery, F., Barriendos, M., Mayer, H., and Glaser, R.: Hydrometeorological reconstruction of the 1824 flood event in the Neckar River basin (southwest Germany), Hydrolog. Sci. J., 51, 864-877, https://doi.org/10.1623/hysj.51.5.864, 2006.

Camenisch, C.: Endlose Kälte. Witterungsverlauf und Getreidepreise in den Burgundischen Niederlanden im 15. Jahrhundert, Schwabe Verlag (Wirtschafts-, Sozial- und Umweltgeschichte, Band 5), Basel, Switzerland, 2015.

Camenisch, C., Keller, K. M., Salvisberg, M., Amann, B., Bauch, M., Blumer, S., Brázdil, R., Brönnimann, S., Büntgen, U., Campbell, B. M. S., Fernández-Donado, L., Fleitmann, D., Glaser, R., González-Rouco, F., Grosjean, M., Hoffmann, R. C., Huhtamaa, H., Joos, F., Kiss, A., Kotyza, O., Lehner, F., Luterbacher, J., Maughan, N., Neukom, R., Novy, T., Pribyl, K., Raible, C. C., Riemann, D., Schuh, M., Slavin, P., Werner, J. P., and Wetter, O.: The 1430s: a cold period of extraordinary internal climate variability during the early Spör Minimum with social and economic impacts in north-western and central Europe, Clim. Past, 12, 2107-2126, https://doi.org/10.5194/cp-12-2107-2016, 2016.

Centralstelle des Landwirtschaftlichen Vereins Karlsruhe (Hg.): Landwirtschaftliches Wochenblatt für das Großherzogtum Baden, Jg. 1-19 (1833-1851), 1845.

Chouard, P.: Vernalization and its relations to dormancy, Ann. Rev. Plant Physio., 11, 191-238, https://doi.org/10.1146/annurev.pp.11.060160.001203, 1960.

Cook, R. D. and Weisberg, S.: Residuals and Influence in Regression, Chapman and Hall, London, UK, 1982.

Diamond, J.: Collapse: how societies choose to fail or succeed, Viking, New York, USA, 2005.

Dürr, F.: Chronik der Stadt Heilbronn 741-1895, Heilbronn, Germany, 1895.

Engbersen, G., Snel, E., and de Boom, J.: "A van full of Poles": Liquid migration from Central and Eastern Europe, in: A Continent Moving West? EU Enlargement and Labour Migration from Central and Eastern Europe, edited by: Black, R., Engbersen, G., Okólski, M., and Panţîru, C., Amsterdam University Press, Amsterdam, the Netherlands, 115-140, 2010.

Engler, S., Mauelshagen, F., Werner, J., and Luterbacher, J.: The Irish famine of 1740-1741: famine vulnerability and "climate migration", Clim. Past, 9, 1161-1179, https://doi.org/10.5194/cp-9-1161-2013, 2013.

Fagan, B.: The Great Warming: Climate change and the rise and fall of civilizations, Bloomsbury Press, New York, USA, 2008.

Fasel, M.: STI: Calculation of the Standardized Temperature Index, R package version 0.1, available at: http://CRAN.R-project.org/ package=STI (last access: 31 January 2017), 2015.

Fies, A.: Die badische Auswanderung im 19. Jahrhundert nach Nordamerika unter besonderer Berücksichtigung des Amtsbezirks Karlsruhe zwischen 1880-1914, Karlsruhe, Germany, 2010. 
Fleischmann, S.: Die Agrarkrisis von 1845-1855 mit besonderer Berücksichtigung von Baden, Diss. Heidelberg, Germany, 1902.

Freiburger Zeitung: Freiburg 1784-1943, edition from 2 May 1832, available at: https://fz.ub.uni-freiburg.de/show/fz.cgi? $\mathrm{cmd}=$ showpic $\&$ ausgabe $=04 \&$ day $=02 \&$ year $=1832 \&$ month $=$ $05 \&$ project=3\&anzahl $=4,1832$.

Freiburger Zeitung: Freiburg 1784-1943, edition from 7 May 1847, available at: https://fz.ub.uni-freiburg.de/show/fz.cgi? $\mathrm{cmd}=$ showpic $\&$ ausgabe $=01 \&$ day $=07 \mathrm{~g} \&$ year $=1847 \&$ month $=$ 05\&project=3\&anzahl=4, 1847a.

Freiburger Zeitung: Freiburg 1784-1943, edition from 14 May 1847, available at: https://fz.ub.uni-freiburg.de/show/fz.cgi? $\mathrm{cmd}=$ showpic \&ausgabe $=01 \&$ day $=14 \mathrm{~g} \&$ year $=1847 \&$ month $=$ 05\&project=3\&anzahl $=4,1847 \mathrm{~b}$.

Freiburger Zeitung: Freiburg 1784-1943, edition from 18 May 1847, available at: https://fz.ub.uni-freiburg.de/show/fz.cgi? $\mathrm{cmd}=$ showpic \&ausgabe $=04 \&$ day $=18 \mathrm{~g} \&$ year $=1847 \&$ month $=$ $05 \&$ project=3\&anzahl $=4,1847 \mathrm{c}$.

Gehlinger, G.: Überblick über die Entwicklung der Landwirtschaft in Württemberg seit der Mitte des 18. Jahrhunderts, in: WJB 1897, I, 49-76, 1897.

Glaser, R.: Klimageschichte Mitteleuropas: 1200 Jahre Wetter, Klima, Katastrophen, Darmstadt, Germany, 2013.

Glaser, R. and Riemann, D.: A thousand-year record of temperature variations for Germany and Central Europe based on documentary data, J. Quaternary Sci., 24, 437-449, https://doi.org/10.1002/jqs.1302, 2009.

Glaser, R., Riemann, D., Schönbein, J., Barriendos, M., Brázdil, R., Bertolin, C., Camuffo, D., Deutsch, M., Dobrovolný, P., van Engelen, A., Enzi, S., Halícková, M., Koenig, S., Kotyza, O., Limanówka, D., Macková, J., Sghedoni, M., Martin, B., and Himmelsbach, I.: The variability of European floods since AD 1500, Clim. Change 101, 235-256, https://doi.org/10.1007/s10584010-9816-7, 2010.

Gross, J. and Ligges, U.: nortest: Tests for Normality, available at: http://CRAN.R-project.org/package=nortest (last access: 31 January 2017), 2015.

Großherzoglich-Badisches Regierungsblatt, Karlsruhe, Germany, 1803-1868.

Großherzogtum Baden: Ministerium des Innern: Übersicht über die Auswanderung im Großherzogtum Baden in den Jahren 1840 bis mit 1855, Karlsruhe, 1857.

Grove, J. M.: The Little Ice Age, Methuen, London, UK, 1988.

Güll, R.: Auswanderung aus Württemberg und Baden, in: Statistisches Monatsheft Baden-Württemberg 09, 41-48, 2013.

Hammar, T., Brochmann, G., Tams, K., and Faist, T.: International migration, immobility and development, multidisciplinary perspectives, Berg, Oxford, UK, 1997.

Hansen, C.: Die deutsche Auswanderung im 19. Jahrhundert - ein Mittel zur Lösung sozialer und sozialpolitischer Probleme?, in: Deutsche Amerikaauswanderung im 19. Jahrhundert, edited by: Moltmann, G., Stuttgart, Germany, 1976.

Harrell Jr., F. E., with contributions from Charles Dupont and many others: Hmisc: Harrell Miscellaneous, R package version 3.174, available at: http://CRAN.R-project.org/package=Hmisc (last access: 31 January 2017), 2016.

Harris, I., Jones, P. D., Osborn, T. J., and Lister, D. H.: Updated high-resolution grids of monthly climatic observations
- the CRU TS3.10 Dataset, Int. J. Climatol., 34, 623-642, https://doi.org/10.1002/joc.3711, 2014.

Herrmann, B.: Kartoffel, Tod und Teufel, in: “...mein Acker ist die Zeit”: Aufsätze zur Umweltgeschichte, Universitätsverlag, Göttingen, Germany, 293-342, 2011.

Heünisch, A. J. V.: Das Großherzogtum Baden, historischgeographisch-statistisch-topographisch beschrieben, Mit Beigaben von J. Bader, Heidelberg, 1857.

Himmelsbach, I., Glaser, R., Schoenbein, J., Riemann, D., and Martin, B.: Reconstruction of flood events based on documentary data and transnational flood risk analysis of the Upper Rhine and its French and German tributaries since AD 1480, Hydrol. Earth Syst. Sci., 19, 4149-4164, https://doi.org/10.5194/hess-19-41492015, 2015.

Hugo, G.: Environmental concerns and international migration, Int. Migr. Rev., 30, 105-131, https://doi.org/10.2307/2547462, 1996.

Hunter, L. M.: Migration and environmental hazards, Popul. Environ., 26, 273-302, https://doi.org/10.1007/s11111-005-3343-x, 2005.

IPCC: Climate Change 2014: Synthesis Report. Contribution of Working Groups I, II and III to the Fifth Assessment Report of the Intergovernmental Panel on Climate Change, Core Writing Team, edited by: Pachauri, R. K. and Meyer, L. A., IPCC, Geneva, Switzerland, 151 pp., 2014.

Krämer, D.: "Menschen grasten mit dem Vieh". Die letzte grosse Hungerkrise der Schweiz 1816/1817, Wirtschafts-, Sozial- und Umweltgeschichte (WSU), 4, Schwabe Verlag, Basel, Switzerland, 528 pp., 2015.

Lamb, H. H.: Climate history and the modern world, Methuen, London, UK, 1982.

Lee, E. S.: A theory of migration, Demography, 3, 47-57, 1966.

Linden, E.: The winds of change: Climate, weather, and the destruction of civilizations, Simon and Schuster, New York, UK, 2006.

Lutz, W., Prskawetz, A., and Sanderson W. C.: Introduction, in: Population and Environment: Methods of Analysis, Population Council, New York, 1-21, 2002.

Marschalck, P.: Deutsche Überseewanderung im 19. Jahrhundert. Ein Beitrag zur soziologischen Theorie der Bevölkerung, KlettCotta, Stuttgart, Germany, 1973.

McKee, T. B., Doesken, N. J., and Kleist, J.: The relationship of drought frequency and duration to time scales, in: Preprints, Eighth Conference on Applied Climatology, 17-22 January, Anaheim, California, USA, 179-184, 1993.

McLeman, R. A.: Climate change, migration, and critical international security considerations, International Organization for Migration, Geneva, Switzerland, 2011.

McLeman, R. A.: Climate and Human Migration: Past Experiences, Future Challenges, Cambridge University Press, Cambridge, UK, 2013.

McLeman, R. A. and Smith, B.: Migration as an adaption to climate change, Clim. Change 76, 31-53, https://doi.org/10.1007/s10584-005-9000-7, 2006.

Meier-Braun, K.-H. and Weber, R.: Kleine Geschichte der Ein- und Auswanderung in Baden-Württemberg, DRW-Verlag, Leinfelden-Echterdingen, Germany, 2009.

Megerle, K.: Württemberg im Industrialisierungsprozess Deutschlands: Ein Beitrag zur regionalen Differenzierung der Industrialisierung, Stuttgart, Germany, 1982. 
Oltmer, J.: Migration im 19. und 20. Jahrhundert, Enzyklopädie deutscher Geschichte, Band 86, Oldenbourg, Munich, Germany, 2010.

Oppenheimer, C.: Climatic, environmental and human consequences of the largest known historic eruption: Tambora volcano (Indonesia) 1815, Prog. Phys. Geogr. 27, 230-259, https://doi.org/10.1191/0309133303pp379ra, 2003.

Parry, M.: Climatic change and the agricultural frontier, in: Climate and History, edited by: Wygley, T. M. L., Ingram, M. J., and Farmer, G., Cambridge University Press, Cambrige, UK, 319336, 1981

Pfaff, K.: Geschichte der Stadt Stuttgart nach Archival-Urkunden und anderen bewährten Quellen, 2. Teil, Stuttgart, Germany, 1846.

Pfister, C.: Klimageschichte der Schweiz 1525-1860, P. Haupt, Stuttgart, Germany, 1985.

Pfister, C. and Brázdil, R.: Social vulnerability to climate in the "Little Ice Age": an example from Central Europe in the early 1770s, Clim. Past, 2, 115-129, https://doi.org/10.5194/cp-2-1152006, 2006.

Pribyl, K.: Farming, Famine and Plague, The Impact of Climate in Late Medieval England, Springer, Heidelberg, Germany, 2017.

R Core Team: R: A language and environment for statistical computing. R Foundation for Statistical Computing, Vienna, Austria, available at: http://www.r-project.org/ (last access: 10 November 2017), 2015.

Regierungs-Blatt für das Königreich Württemberg im Auszuge: Vol. 1 (1806-1816) and Vol. 2 (1817-1824), Stuttgart, Germany, 1806-1847.

Schenk, G. J.: Meeresmacht und Menschenwerk. Die Marcellusflut an der Nordseeküste im Januar 1219, in: Katastrophen. Vom Untergang Pompejis bis zum Klimawandel, edited by: Schenk, G. J., Thorbecke, Ostfildern, Germany, 52-66, 2009.

Scheuerbrandt, A.: Die Auswanderung aus dem heutigen BadenWürttemberg nach Preußen in den habsburgischen Südosten, nach Rußland und Nordamerika zwischen 1683 und 1811, in: Kommission für geschichtliche Landeskunde in BadenWürttemberg (Ed.): Historischer Atlas von Baden-Württemberg, 12, 5 (Erläuterungen), 10. Lieferung, Stuttgart, Germany, 1985.

Statistisches Jahrbuch für das Großherzogtum Baden, Karlsruhe, Germany, 1869-1938.

Statistisches Landesamt Baden-Württemberg: Statistische Berichte Baden-Württemberg, Art. No. 3336 15001, 2015.

Statistische Mitteilungen über das Großherzogtum Baden: Bd. 3, No. 8, Karlsruhe, Germany, 1881.

Stieffel, P.: Witterungskunde. Mit Rücksicht auf vermuthliche Witterung überhaupt und des Jahres 1842 insbesondere, Karlsruhe, Germany, 1842.

Stommel, H. and Stommel, E.: Volcano Weather: The Story of 1816. The Year without a Summer, Seven Seas Press, Newport, Rhode Island, USA, 1983.

Tambora: Historical sources, available at: https://www.tambora. org/, last access: 7 November 2017.

Tuchtenhagen, R.: Religiöser Dissens, Staat und Auswanderung nach Osteuropa im 18. und frühen 19. Jahrhundert, in: Migration nach Ost- und Südosteuropa vom 18. bis zum Beginn des 19. Jahrhunderts, Ursachen - Formen - Verlauf - Ergebnis, edited by: Beer, M. and Dahlmann, D., Stuttgart, Germany, 145-162, 1999.
Turner, B. L., Kasperson, R. E., Matson, P. A., McCarthy, J. J., Corell, R. W., and Christensen, L.: A framework for vulnerability analysis in sustainability science, P. Natl. Acad. Sci. USA, 100, 8074-8079, https://doi.org/10.1073/pnas.1231335100, 2003.

Twyrdy, V.: Die Bewältigung von Naturkatastrophen in mitteleuropäischen Agrargesellschaften seit der Frühen Neuzeit, in: Katastrophen machen Geschichte, edited by: Masius, P, Sprenger, J., and Mackowiak, E., Göttingen: Universitätsverlag, Göttingen, Germany, 2010.

Venables, W. N. and Ripley, B. D.: Modern applied statistics with S-Plus, 4th. edn., Statistics and computing, Springer, New York, USA, 2002.

Vicente-Serrano, S. M., Beguería, S., and López-Moreno, J. I.: A Multiscalar Drought Index Sensitive to Global Warming: The Standardized Precipitation Evapotranspiration Index, J. Climate, 23, 1696-1718, https://doi.org/10.1175/2009JCLI2909.1, 2010.

von Hippel, W.: Auswanderung aus Südwestdeutschland: Studien zur württembergischen Auswanderung und Auswanderungspolitik im 18. und 19. Jahrhundert, Stuttgart, Germany, 1984.

von Memminger, J. D. G.: Allgemeine Chronik. Witterung. Theuerung, in: WJB, 3-24, 1818.

von Viebahn, G.: Statistik des zollvereinten und nördlichen Deutschlands, Bd. 3, Georg Reimer, Berlin, Germany, 1868.

Wetter, O., Pfister, C., Werner, J. P., Zorita, E., Wagner, S., Seneviratne, S. I., Herget, J., Grünewald, U., Luterbacher, J., Alcoforado, M. J., Barriendos, M., Bieber, U., Brázdil, R., Burmeister, K. H., Camenisch, C., Contino, A., Dobrovolný, P., Glaser, R., Himmelsbach, I., Kiss, A., Kotyza, O., Labbé, T., Limanówka, D., Litzenburger, L., Nordl, Ø., Pribyl, K., Retsö, D., Riemann, D., Rohr, C., Siegfried, W., Söderberg, J., and Spring, J.-L.: The year-long unprecedented European heat and drought of 1540 - a worst case, Clim. Change, 125, 349-363, https://doi.org/10.1007/s10584-014-1184-2, 2014.

Williams, D. A.: Generalized linear model diagnostics using the deviance and single case deletions, Applied Statistics, 36, 181-191, https://doi.org/10.2307/2347550, 1987.

Wisner, B., Blaikie, P., Cannon, T., and Davis, I.: At Risk: natural Hazards, People's vulnerability and disasters, Routledge, London, UK, 2004.

Württembergisches Jahrbuch für Statistik und Landeskunde (WJB): Stuttgart, Germany, p. 2 ff., 1830.

Württembergisches Jahrbuch für Statistik und Landeskunde (WJB): Stuttgart, Germany, 41-52, 1846.

Württembergisches Jahrbuch für Statistik und Landeskunde (WJB): Stuttgart, Germany, 34-84, 1866.

Württembergisches Jahrbuch für Statistik und Landeskunde (WJB): Stuttgart, Germany, 22-36, 1867.

Württembergisches Jahrbuch für Statistik und Landeskunde (WJB): Stuttgart, Germany, Vol. 2, 1896. 